\title{
High incorporation of magnetite nanoparticles inside tetraaza macrocyclic Schiff base cavity : Spectroscopic characterization and modeling by DFT calculation
}

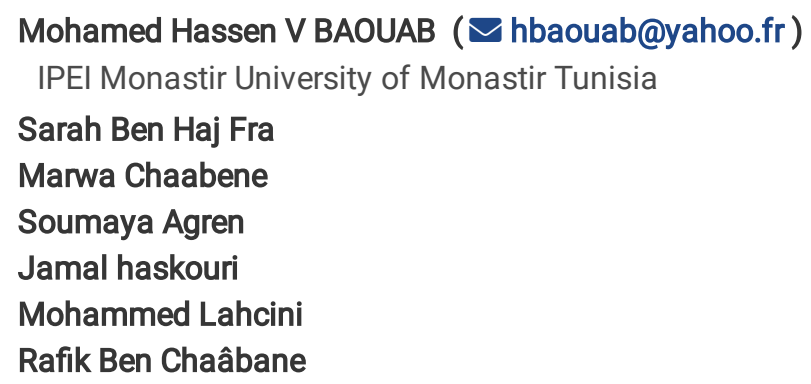

Research Article

Keywords: Schiff bases, co-precipitation, tetraaza macrocycle, nanoparticles, magnetite and DFT

Posted Date: February 7th, 2022

DOI: https://doi.org/10.21203/rs.3.rs-1317700/v1

License: @ (i) This work is licensed under a Creative Commons Attribution 4.0 International License. Read Full License 


\section{Abstract}

This work presents a simple synthesis of tetraaza macrocyclic Schiff base ligand $\left(\mathrm{C}_{40} \mathrm{H}_{28} \mathrm{~N}_{4}\right)$, its complex $\left[\left(\mathrm{C}_{40} \mathrm{H}_{28} \mathrm{~N}_{4}\right) @ \mathrm{Fe}(\mathrm{II})\right]$, and a novel complex of magnetite $\mathrm{Fe}_{3} \mathrm{O}_{4} \mathrm{NPs}$ incorporated inside tetraaza macrocyclic cavity $\left[\left(\mathrm{C}_{40} \mathrm{H}_{28} \mathrm{~N}_{4}\right) @ \mathrm{Fe}_{3} \mathrm{O}_{4} \mathrm{NPs}\right]$ in order to obtain welldispersed nanoparticles. The characterization and structural identification were carried out by ${ }^{1} \mathrm{H} \mathrm{NMR},{ }^{13} \mathrm{C}$ and DEPT $135 \mathrm{NMR}$ spectroscopy as well by X-ray spectroscopy, FT-IR, and finally by ATG using both experimental and theoretical methods. XRD measurements indicate that the presence of Schiff's bases does not modify the crystal structure of the nanoparticles (approximately 11 $\mathrm{nm})$. FT-IR was used to illuminate the presence of $\mathrm{Fe}_{3} \mathrm{O}_{4} \mathrm{NPs}$ in tetrahedral and octahedral sites as well as their coordination with imine $(\mathrm{C}=\mathrm{N})$ of tetraaza macrocyclic. The UV-Vis spectra and frontier molecular orbitals (FMOs) of the title compounds were calculated at TDDFT/CAM-B3LYP-D3/6-311 G (d, p) level of theory. The corresponding calculated results yield shows a good agreement with the experimental data. The morphological characterization of the nanoparticles was carried out by SEM which revealed that the shape of the NPs was generally spherical. The SEM images also show that the nanoparticles prepared by in-situ with co-precipitation method were able to form stable complexes. Thermal characterization by ATG shows that there is $64 \%$ of the magnetite nanoparticles formed in-situ which corresponds to a grafting density of $25 \mathrm{mmol} . \mathrm{g}^{-1}$.

\section{Introduction}

Macrocyclic Schiff bases and their metal complexes have constituted a field of research in continuous development thanks to their appreciable role based on features of cavity size, rigidity and tendency to establish transition metal complexes which have attracted the interest of the coordination and bioinorganic chemists [1-5]. The synthesis of macrocyclic ligands Schiff bases tetradentates, and their transition metal complexes have been widely studied due to their attractive chemical properties and biological activities [6-9] and the presence of amino groups similar to the natural biological structure like Hemoglobin and chlorophyll [10, 11]. In fact, macrocyclic Schiff bases are particularly important in macrocyclic chemistry because of their flexible synthesis, their selectivity, and even their ability to stabilize many metals in various oxidation states [12-16]. However, a huge number of tetraaza macrocyclic $\left(\mathrm{N}_{4}\right)$ metal complexes show interesting biological activities such as antifungal [17, 18], antibacterial [19-21], antimicrobial [22-25] and anticancer [11, 26, 27] effects.

On the other hand, the synthesis of magnetic nanomaterials especially magnetite nanoparticles $\left(\mathrm{Fe}_{3} \mathrm{O}_{4} \mathrm{NPs}\right)$ have been attracted due its biocompatibility that show an important role in nanoscience and nanotechnology [28-30]. Indeed, magnetite is one of the most abundant ferromagnetic minerals on earth. So, magnetite nanoparticles $\left(\mathrm{Fe}_{3} \mathrm{O}_{4} \mathrm{NPs}\right)$ have been intensively studied due to their interesting chemical and magnetic properties such as size, shape, hydrophobicity, surface functionality, and super magnetic character [31-33]. These properties offer the high potential of applications in biomedical and bioengineering fields such as magnetic resonance imaging (MRI) contrast enhancement agent [31, 34], cell separation [35], and drug delivery[30, 36-38]. Actually, magnetic iron oxide $\left(\mathrm{Fe}_{3} \mathrm{O}_{4}\right)$, which has an inverse spinel structure, forms face-centred cubic with oxygen and in the interstitial octahedral sites and tetrahedral sites are occupied by iron which is present under $\mathrm{Fe}^{2+}$ and $\mathrm{Fe}^{3+}$ oxidation states $[28,39]$. Several methods have been reported in the literature on the synthesis of oxide nanomaterials such as hydrothermal synthesis [40-42], sol-gel [43, 44] and co-precipitation, etc... Compared to other methods, co-precipitation is the most convenient way to synthesize the magnetic iron oxide nanoparticles because of its lower reaction temperature, easy operation, high nanocrystal purity, and eco-friendly procedure $[45,46]$.

However, the co-precipitation method usually shows the difficulty to control nanoparticle size and distribution size due to the strong dipole-dipole interactions which lead to the formation of $\mathrm{Fe}_{3} \mathrm{O}_{4} \mathrm{NPs}$ aggregated. So, the deterioration of magnetic proprieties $[19,47]$.

To conserve these magnetic proprieties of NPs, Chaabane et al., [19] succeeded in synthesizing magnetite $\mathrm{Fe}_{3} \mathrm{O}_{4} \mathrm{NPs}_{\text {incorporated in the }}$ tetraaza macrocyclic Schiff base cavity. Therefore, the NPs were successfully dispersed and their size was controlled by keeping magnetic proprieties which have shown a very interesting biological activity.

The aim of this work was the synthesis of a tetraaza macrocycle Schiff base ligand more stable and conjugated from the condensation of benzil and o-phenylenediamine followed by the complexation of iron (II) with the ligand as intermediate. Then, the growth in-situ of the $\mathrm{Fe}_{3} \mathrm{O}_{4} \mathrm{NPs}$ inside the tetraaza macrocyclic was produced by a novel co-precipitation technique. All these products were studied experimentally as well as theoretically by many physic-chemical techniques like XRD, NMR, FT-IR, UV-VISIBLE. Furthermore, in this paper, SEM, TGA, and VSM have been employed to characterize and evaluate the incorporation of magnetite NPs onto tetraaza macrocycle.

\section{Experimental Procedure}




\subsection{Materials and methods}

\subsubsection{Materials used}

Chemicals and solvents used were purchased commercially obtainable element grade and used without purification. Benzil, ophenylenediamine, ethanol, DMSO, ferrous sulfate heptahydrate $\left(\mathrm{FeSO}_{4} \cdot 7 \mathrm{H}_{2} \mathrm{O}\right)$, ferric chloride hexahydrate $\left(\mathrm{FeCl}_{3} .6 \mathrm{H}_{2} \mathrm{O}\right)$ salts, and ammonium hydroxide $\left(\mathrm{NH}_{4} \cdot \mathrm{OH}\right)$ were procured from Sigma-Aldrich, France.

\subsubsection{Characterizations}

${ }^{1} \mathrm{H} \mathrm{NMR}(300 \mathrm{MHz})$ and ${ }^{13} \mathrm{C}(75 \mathrm{MHz})$ spectra were measured by Burker 300 spectrometer in DMSO- $\mathrm{d}_{6}$. The infrared spectra FTIR were recorded in the range of $4000-400 \mathrm{~cm}^{-1}$ using a Perkin Elmer spectrum in $\mathrm{KBr}$ disks. The UV-VIS absorption spectra were measured by spectrophotometer UV-visible SPECORD/200 plus. The field emission scanning electron microscope (SEM) and the energy dispersive Xray (EDX) were taken by (SEM, FEl Quanta 250 FEG, Eindhoven, Netherlands) Powder X-ray diffraction (XRD) was carried out using a Bruker D8 Advance diffractometer with monochromatic Cu Ka source operated at $40 \mathrm{kV}$ and $40 \mathrm{~mA}$. Patterns were collected in steps of $0.02^{\circ}(2 \theta)$ over the angular range $1-10.0^{\circ}(2 \theta)$, with an acquisition time of $25 \mathrm{~s}$ per step. Additionally, XRD patterns were recorded over a wider angular range, $10-80^{\circ}(2 \theta)$ to determine the presence of segregated crystalline phases. TGA curves were recorded with a Setaram Setsys $16 / 18$ thermobalance under an $\mathrm{N}_{2}$ atmosphere flowing at $25 \mathrm{~mL}$ per min (heating rate of $5^{\circ} \mathrm{C} / \mathrm{min}$ ). The magnetic proprieties were measured using a superconducting quantum design (MPMS, SQUIR-VSM).

\subsection{Quantum chemical calculation}

The optimized structural parameters of synthesized compounds have been performed at DFT/B3LYP [48] with the empirical dispersion correction D3 of Grimme and al [49] methods with 6-311G (d, p) basis sets using the Gaussian 09 program [50]. B3LYP-D3/6-311G (d, p) was found to provide a good compromise between accuracy and computation time for structure optimizations. Also, we have found that B3LYP-D3 gives the lowest gap energy and is the closest to the experimental results when compared to the other functional ones. Moreover, 6-311G $(d, p)$ was commonly used in literature [51, 52] where it indicates an efficient and robust basis for III-V semiconductor computations [53]. The ${ }^{1} \mathrm{H}$ and ${ }^{13} \mathrm{C}$ NMR calculations utilized the Gauge-Independent Atomic Orbital (GIAO) [54] method. In all cases, ${ }^{1} \mathrm{H}$ and ${ }^{13} \mathrm{C}$ NMR for the test molecules were corrected with chemical shift $\delta(\mathrm{ppm})$ relative to computed values for tetramethylsilane (TMS), simulated at the same level [55].

Vibrational frequencies have been carried out with the same method as geometry optimization in the gas phase. It has been confirmed that these structures correspond to the characteristics of the local minimum by the absence of an imaginary mode. The simulated harmonic vibrational wavenumbers were scaled down uniformly by a factor of 0.967 for B3LYP-D3/6-311G (d, p) level of theory, which accounts for systematic errors caused by basis set incompleteness, vibrational anharmonicity, and neglect of electron correlation [56].

The electronic absorption spectra for optimized molecule calculated at the time-dependent density functional theory (TD-DFT) with CAMB3LYP-D3/6-311G (d, p) level of theory $[57,58]$ which is used to compute energies oscillator and the absorption wavelengths in DMSO solvent. The visualizations were performed by the graphical interfaces Gaussview [59].

Moreover, by using the energies of the highest occupied molecular orbital (HOMO) ( $\left.\mathrm{E}_{\text {HOMO }}\right)$ and the lowest unoccupied molecular orbital (LUMO) ( $\left.E_{\text {LUMO }}\right)$ for a molecule, electronic gap energy $\left(E_{g}\right)$, chemical potential $(\boldsymbol{\mu})$, global hardness $(\boldsymbol{\eta})$ and global softness $(\boldsymbol{\sigma})$ can be calculated as follows [60]: $E_{g} \approx E_{\text {LUMO }}-E_{\text {HOMO }}$ (Electronic gap energy), $\mu=-\left[E_{\text {HOMO }}+E_{\text {LUMO }}\right] / 2$ (chemical potential),

$\eta=\left[E_{\text {LUMO }}-E_{\text {Hомо }}\right] / 2$ (Global hardness) and $\sigma=1 / \eta$ (global softness). The chemical potential ( $\mu$ ) characterizes the escaping tendency of electrons from a stable system. The chemical hardness $(\eta)$ measures the resistance of a molecule to charge transfer. The global softness $(\sigma)$ is the capacitance of the molecule to acquire charge.

\section{Results And Discussion}

\subsection{Chemical synthesis}

Synthesis of 6,7,14,15-tetrapheyldibenzo-1,4,7,10-tetraazadodecine ligand ( $\mathrm{C}_{40} \mathrm{H}_{28} \mathrm{~N}_{4}$ ) 
The ligand (1) was prepared by dissolving benzil $(1 \mathrm{~g}, 4.76 \mathrm{mmol})$ in $10 \mathrm{ml}$ of ethanol in the presence of few drops of concentrated sulfuric acid $\left(\mathrm{H}_{2} \mathrm{SO}_{4}\right)$ in a $250 \mathrm{ml}$ round bottom flask. Thus, o-phenylenediamine $(0.52 \mathrm{~g}, 4.76 \mathrm{mmol})$ was added slowly and was mixed with constant stirring. This mixture was refluxed at $78^{\circ} \mathrm{C}$ for $24 \mathrm{~h}$. On cooling, grey crystals precipitate was formed, which was filtered, washed with cold $\mathrm{EtOH}$, and dried under vacuum over anhydrous $\mathrm{MgCl}_{2}$. The whole reaction is shown in Scheme 1 .

Synthesis of the Fe (II) complex

Fe (II) complex (2) was prepared by condensation method because the yield of the complex was law as soon as the metal (II) was added with ligand $\left(\mathrm{C}_{40} \mathrm{H}_{28} \mathrm{~N}_{4}\right)$. A hot stirring ethanolic solution (20ml) of o-phenylendiamine ( $2 \mathrm{mmol}$ ) was slowly added to bivalent metal salt $\mathrm{Fe}\left(\mathrm{SO}_{4}\right) \cdot 7 \mathrm{H}_{2} \mathrm{O}(2 \mathrm{mmol})$. The reaction mixture was heated at $78^{\circ} \mathrm{C}$ under Argon atmosphere for $30 \mathrm{~min}$. then, benzil ( $\left.2 \mathrm{mmol}\right)$ was added to the refluxing mixture, and refluxing was continued for $24 \mathrm{~h}$ as depicted in Scheme 1. Finally, the solid product precipitate was filtered washed with ethanol, and dried under vacuum.

Synthesis of $\left[\left(\mathrm{C}_{40} \mathrm{H}_{28} \mathrm{~N}_{4}\right) @ \mathrm{Fe}{ }_{3} \mathrm{O}_{4} \mathrm{NPs}\right]$

The preparation of free nanoparticles by the co-precipitation method was widely mentioned in the literature thanks to their different applications. On the other hand, the germination of magnetite nanoparticles in-situ on the metal ion complexed in the macrocycle (3) is the novelty of our work. $1.5 \mathrm{~g}$ of $\left[\left(\mathrm{C}_{40} \mathrm{H}_{28} \mathrm{~N}_{4}\right) @ \mathrm{Fe}(\mathrm{II})\right]$ complex is introduced into $250 \mathrm{ml}$ flask previously synthesized in $200 \mathrm{ml}$ of an ethanol/water mixture (ratio $2: 1$ ) with severely stirring at $70^{\circ} \mathrm{C}$.

Then, $3 \mathrm{~g}$ of $\mathrm{FeCl}_{3} \cdot 6 \mathrm{H}_{2} \mathrm{O}$ was added as a source of $\mathrm{Fe}^{3+}$ ions to the solution. The mixture was reacted for 30 min with constant stirring. After, $20 \mathrm{ml}$ of $\mathrm{NH}_{4} \mathrm{OH}(8 \mathrm{M})$ was injected dropwise into the solution until $\mathrm{pH}$ raised to about 10, and stirring continued for $1 \mathrm{~h}$. The colour of the solution was changed from orange to dark brown and then became black denoting the formation of $\mathrm{Fe}_{3} \mathrm{O}_{4} \mathrm{NPs}$ inside the tetraaza macrocyclic Schiff base ligand. Finally, the solid product was filtered, washed with ethanol and water to remove impurities, and dried under vacuum at $60^{\circ} \mathrm{C}$ to remove the excess water. The reaction process is represented in Scheme 1.

Table 1 groups all the proprieties of (1) $\left(\mathrm{C}_{40} \mathrm{H}_{28} \mathrm{~N}_{4}\right)$ ligand, (2) $\left[\left(\mathrm{C}_{40} \mathrm{H}_{28} \mathrm{~N}_{4}\right) @ \mathrm{Fe}(\mathrm{II})\right]$ and (3) $\left[\left(\mathrm{C}_{40} \mathrm{H}_{28} \mathrm{~N}_{4}\right) @ \mathrm{Fe}_{3} \mathrm{O}_{4} \mathrm{NPs}\right]$ complex.

Table 1

The characteristics of the all-synthesized products.

\begin{tabular}{|llll|}
\hline Products & Yield & Melting Point & Colour \\
\hline$\left(\mathrm{C}_{40} \mathrm{H}_{28} \mathrm{~N}_{4}\right){ }^{(1)}$ & $70 \%$ & $120^{\circ} \mathrm{C}$ & grey crystals \\
\hline$\left[\left(\mathrm{C}_{40} \mathrm{H}_{28} \mathrm{~N}_{4}\right) @ \mathrm{Fe}(\mathrm{II})\right]^{(2)}$ & $80 \%$ & $124^{\circ} \mathrm{C}$ & Brown crystals \\
\hline$\left[\left(\mathrm{C}_{40} \mathrm{H}_{28} \mathrm{~N}_{4}\right) @ \mathrm{Fe}_{3} \mathrm{O}_{4} \mathrm{NPs}\right]{ }^{(3)}$ & $96 \%$ & $>300^{\circ} \mathrm{C}$ & Brown crystals \\
\hline
\end{tabular}

\subsection{XRD}

The presence of sharp peaks in the spectrum of the ligand (Fig. 1a) exhibits the crystalline nature of the product. The crystallinity and the intensity of peaks slightly decrease by adding the metal center (Fig. 1b) and the nanoparticles (Fig. 1C) to the ligand [61, 62].

As seen from Fig. 1c, the PXRD pattern of the $\left[\left(\mathrm{C}_{40} \mathrm{H}_{28} \mathrm{~N}_{4}\right) @ \mathrm{Fe}_{3} \mathrm{O}_{4} \mathrm{NPs}\right]$ complex whose magnetite nanoparticle is incorporated into the macrocycle has peaks at $2 \Theta=31.19^{\circ} ; 35.61^{\circ} ; 43.25^{\circ} ; 54.47^{\circ} ; 57.41^{\circ}$ and $62.95^{\circ}$ which are assigned respectively to the reticular planes of Miller indices (hkl) (220), (311), (400), (422), (511), and (440). It also confirms the presence of magnetite nanoparticles in facecentered cubic spatial geometry (fcc) in its structure [63]. Besides, the absence of the most intense peak (311) in the free ligand spectrum (a) $\left(\mathrm{C}_{40} \mathrm{H}_{28} \mathrm{~N}_{4}\right)$, and (b) the $\left[\left(\mathrm{C}_{40} \mathrm{H}_{28} \mathrm{~N}_{4}\right) @ \mathrm{Fe}(\mathrm{II})\right]$ complex confirms more the germination of the nanoparticles in-situ on the complexed $\mathrm{Fe}(\mathrm{II})$ metal ion [64].

In addition, the XRD spectrum of $\left[\left(\mathrm{C}_{40} \mathrm{H}_{28} \mathrm{~N}_{4}\right) @ \mathrm{Fe}_{3} \mathrm{O}_{4} \mathrm{NPs}\right]$ (Fig. 1c) reveals that the in-situ growth of the $\mathrm{Fe}_{3} \mathrm{O}_{4}$ magnetite nanoparticles in the tetraaza cavity did not cause a noticeable change in the crystallographic properties of the ligand, which confirms its great stability under the effect of the hyperconjugation. To calculate the size of the nanoparticles developed in-situ, we use the FWHM of the most intense peak (311) according to the following Debye Scherrer equation [65]:

Page $4 / 23$ 
$D=\frac{k}{\lambda \beta \cos (\theta)}$

With $D$ is the average size of the crystallite, $\lambda$ is the wavelength of CuKa radiation $(\lambda=0.154 \mathrm{~nm}), \mathrm{k}$ is the grain shape factor, considering that the particles are spherical in shape $k$ takes the value $0.89(0.9) . \beta$ is the broadening of diffraction line measured at half maximum in intensity and $\theta$ is the Bragg angle of the peak (311). The calculation of $D$ from this equation gives an average size of the $\mathrm{Fe}_{3} \mathrm{O}_{4}$ nanoparticles complexed in the tetraaza cavity of the macrocycle around $11 \mathrm{~nm}$ [66]. This very important result confirms our success in the germination of magnetite nanoparticles in the cavity of a macrocycle from complexed metal ions.

Furthermore, the molecular geometries of (a), (b) and (c), presented in Fig. 2, were optimized at B3LYP-D3/6-311 G (d, p) levels. Geometric parameters of these compounds such as the bond lengths $(\AA)$ and bond angles $\left(^{\circ}\right)$ are shown in Table 2 . They were simulated with the assumption that the solvent used for crystallization is ethanol. In crystallography, the title compounds study has $\mathrm{C} 1$ type symmetry. The molecular structure of the ligand (a) $\left(\mathrm{C}_{40} \mathrm{H}_{28} \mathrm{~N}_{4}\right)$ exhibits non-planar distortions of the macrocyclic tetraaza cavity. As shown in Fig. 2 and Table 2, the macrocyclic tetraaza cavity of (b) $\left[\left(\mathrm{C}_{40} \mathrm{H}_{28} \mathrm{~N}_{4}\right) @ \mathrm{Fe}(\mathrm{II})\right]$ becomes more planar after the addition of the iron Fe metallic center on the ligand (a) $\left(\mathrm{C}_{40} \mathrm{H}_{28} \mathrm{~N}_{4}\right)$, where the Fer (II) center metal is coordinated by four $\mathrm{N}$ atoms of the cavity: $\left(\mathrm{N}_{1}-\mathrm{Fe}_{1}-\mathrm{N}_{3}\right.$ and $\mathrm{N}_{2}-\mathrm{Fe}_{1}-\mathrm{N}_{4}$ are equal to $163^{\circ}$ ) and the distance $\mathrm{Fe}-\mathrm{N}$ in the range [1.793-1.807 ( $(\AA)$ ]. In addition, we notice that complex $\left[\left(\mathrm{C}_{40} \mathrm{H}_{28} \mathrm{~N}_{4}\right) @ \mathrm{Fe}_{3} \mathrm{O}_{4} \mathrm{NPs}\right]$ (c) exhibits non-planar distortions of the macrocyclic tetraaza cavity due to the displacement of the iron cation toward the $\mathrm{Fe}_{3} \mathrm{O}_{4} \mathrm{NPs}$. These deformations are clarified using X-ray molecular structures of (c) which shows clearly that the $\mathrm{Fe}_{3} \mathrm{O}_{4} \mathrm{NPs}$ have been successfully encapsulated in the macrocyclic tetraaza cavity. 
Table 2

Selected bond distances $(\AA)$ and angles $\left(^{\circ}\right)$ in the molecular structures of (a), (b) and (c).

\begin{tabular}{|c|c|c|c|c|c|c|c|}
\hline \multicolumn{4}{|c|}{ Length $_{\text {Th }}(\AA)$} & \multicolumn{4}{|l|}{ Angle $_{\mathrm{Th}}(\cdot)$} \\
\hline Atoms & (a) & (b) & (c) & Atoms & (a) & (b) & (c) \\
\hline$N_{1}-C_{1}$ & 1.405 & 1.420 & 1.389 & $\mathrm{C}_{1}-\mathrm{N}_{1}-\mathrm{C}_{8}$ & 123 & 123 & 130 \\
\hline$C_{1}-C_{2}$ & 1.418 & 1.427 & 1.427 & $\mathrm{C}_{2}-\mathrm{N}_{2}-\mathrm{C}_{3}$ & 123 & 128 & 128 \\
\hline $\mathrm{C}_{2}-\mathrm{N}_{2}$ & 1.406 & 1.420 & 1.402 & $\mathrm{C}_{4}-\mathrm{N}_{3}-\mathrm{C}_{5}$ & 128 & 131 & 132 \\
\hline $\mathrm{N}_{2}-\mathrm{C}_{3}$ & 1.273 & 1.426 & 1.331 & $\mathrm{C}_{7}-\mathrm{N}_{4}-\mathrm{C}_{6}$ & 129 & 134 & 130 \\
\hline $\mathrm{C}_{3}-\mathrm{C}_{4}$ & 1.526 & 1.370 & 1.439 & $N_{1}-F_{1}-N_{3}$ & - & 163 & 114 \\
\hline $\mathrm{C}_{4}-\mathrm{N}_{3}$ & 1.280 & 4.403 & 1.326 & $\mathrm{~N}_{2}-\mathrm{Fe}_{1}-\mathrm{N}_{4}$ & - & 163 & 150 \\
\hline $\mathrm{N}_{3}-\mathrm{C}_{5}$ & 1.399 & 1.420 & 1.390 & $\mathrm{O}_{1}-\mathrm{Fe}_{1}-\mathrm{O}_{3}$ & - & - & 90 \\
\hline$C_{5}-C_{6}$ & 1.418 & 1.425 & 1.430 & $\mathrm{O}_{1}-\mathrm{Fe}_{1}-\mathrm{O}_{2}$ & - & - & 56 \\
\hline $\mathrm{C}_{6}-\mathrm{N}_{2}$ & 1.383 & 4.420 & 1.396 & $\mathrm{O}_{2}-\mathrm{Fe}_{1}-\mathrm{O}_{3}$ & - & - & 56 \\
\hline $\mathrm{N}_{2}-\mathrm{C}_{7}$ & 1.273 & 1.403 & 1.348 & $\mathrm{Fe}_{2}-\mathrm{O}_{2}-\mathrm{Fe}_{3}$ & - & - & 72 \\
\hline$C_{7}-C_{8}$ & 1.521 & 1.370 & 1.424 & $\mathrm{Fe}_{2}-\mathrm{O}_{4}-\mathrm{Fe}_{3}$ & - & - & 73 \\
\hline $\mathrm{C}_{8}-\mathrm{N}_{1}$ & 1.277 & 1.426 & 1.338 & - & - & - & - \\
\hline $\mathrm{Fe}_{1}-\mathrm{N}_{1}$ & - & 1.793 & 1.947 & - & - & - & - \\
\hline $\mathrm{Fe}_{1}-\mathrm{N}_{2}$ & - & 1.793 & 1.881 & - & - & - & - \\
\hline $\mathrm{Fe}_{1}-\mathrm{N}_{3}$ & - & 1.807 & 1.939 & - & - & - & - \\
\hline $\mathrm{Fe}_{1}-\mathrm{N}_{4}$ & - & 1.807 & 1.838 & - & - & - & - \\
\hline $\mathrm{Fe}_{1}-\mathrm{O}_{1}$ & - & - & 1.904 & - & - & - & - \\
\hline $\mathrm{Fe}_{1}-\mathrm{O}_{2}$ & - & - & 1.998 & - & - & - & - \\
\hline $\mathrm{Fe}_{1}-\mathrm{O}_{3}$ & - & - & 1.896 & - & - & - & - \\
\hline $\mathrm{Fe}_{2}-\mathrm{O}_{1}$ & - & - & 1.662 & - & - & - & - \\
\hline $\mathrm{Fe}_{2}-\mathrm{O}_{2}$ & - & - & 1.767 & - & - & - & - \\
\hline $\mathrm{Fe}_{2}-\mathrm{O}_{4}$ & - & - & 1.760 & - & - & - & - \\
\hline $\mathrm{Fe}_{3}-\mathrm{O}_{2}$ & - & - & 1.773 & - & - & - & - \\
\hline $\mathrm{Fe}_{3}-\mathrm{O}_{3}$ & - & - & 1.671 & - & - & - & - \\
\hline $\mathrm{Fe}_{3}-\mathrm{O}_{4}$ & - & - & 1.753 & - & - & - & - \\
\hline
\end{tabular}

\subsection{NMR Spectrum analysis}

To confirm the structure of the synthesized products (a) ligand $\left(\mathrm{C}_{40} \mathrm{H}_{28} \mathrm{~N}_{4}\right),\left(\right.$ b) $\left[\left(\mathrm{C}_{40} \mathrm{H}_{28} \mathrm{~N}_{4}\right) @ \mathrm{Fe}(\mathrm{II})\right]$ and (c) $\left[\left(\mathrm{C}_{40} \mathrm{H}_{28} \mathrm{~N}_{4}\right) @ \mathrm{Fe} \mathrm{O}_{3} \mathrm{O}_{4} \mathrm{NPs}\right]$, the ${ }^{1} \mathrm{H}$ and ${ }^{13} \mathrm{C}$ NMR of ligand and complexes have been recorded in DMSO-d6 solution using TMS as an internal standard. Gauge including atomic orbital (GIAO) ${ }^{1} \mathrm{H}$ and ${ }^{13} \mathrm{C}$ NMR chemical shift calculation of the title compounds were calculated at B3LYP-D3/6-311G (d, p) and compared to the experimental data, then their corresponding assignments were listed in Table 3. In fact, the synthesized macrocyclic ligand admits a double symmetry as shown schematically in Fig. $3 \mathrm{~A}$. This symmetry is clearly seen in the ${ }^{1} \mathrm{H}$ NMR spectra by the 
presence only of a quarter of the protons in the structure [67]. In addition, we noticed that our ligand is a macrocycle more or less flat and having a $\pi-\sigma$ type hyperconjugation. This behaviour creates a large cycle current generated by the magnetic field of the device i.e. the movement of electrons $\pi$ induces a large magnetic anisotropy whose axis is perpendicular to the macrocycle plane that primarily affects the chemical shift of protons and carbons [68] (Fig. 3B). The protons inside this cone are strongly shielded which is not the case in our macrocycle since there are no protons inside it, while protons or carbons on the outside are cleared, which explains the increase in the values of chemical shifts.

The H-NMR data for ligand $\left(\mathrm{C}_{40} \mathrm{H}_{28} \mathrm{~N}_{4}\right)($ Table 3 and Fig. $4 a)$ does not show any signal corresponding to the primary amino protons. This suggests that the proposed Schiff base macrocyclic has been formed. It mainly shows signals between 7.30-8.17 ppm, which correspond to aromatic protons, and these experimental results are clearly confirmed by the theoretical results. Indeed, the aromatic protons of disubstituted benzene appear in the form of a multiple at $\delta \mathrm{H}(4 \mathrm{H}, 8.15 \mathrm{ppm})$ corresponds to the most released protons of the anisotropic shielding cone (i.e. the most shielded) which are $\mathrm{H}_{3}, \mathrm{H}_{4}, \mathrm{H}_{3}^{\prime}$, and $\mathrm{H}_{4}^{\prime}$ which theoretically attributable to the most shielded signal at $8.18 \mathrm{ppm}$. Another multiple towards $\mathrm{\delta H}(4 \mathrm{H}, 7.88 \mathrm{ppm})$ corresponds to the protons closest to the anisotropic shielding cone, which are $\mathrm{H}_{2}, \mathrm{H}_{5}, \mathrm{H}_{2}$, and $\mathrm{H}_{5}$ as shown in theoretical spectra at $7.85 \mathrm{ppm}$. All of the aromatic protons of monosubstituted benzene resonate as a massive $\delta \mathrm{H}(2 \mathrm{H}, 7.3-7.5 \mathrm{ppm})$ and are theoretically shown between (7.45-7.90). Therefore, the integration curves are almost in agreement with the number of protons in the structure, which of course confirms the structure of the ligand synthesized. The ${ }^{13} \mathrm{C}$ NMR spectrum of the Schiff base tetradentate (Fig. 4b) mainly presented 11 characteristic signals, the main signal of which is observed towards $\delta C(153.05 \mathrm{ppm})$ corresponds to the azomethine functions $(C=N)$ which by an inductive attracting effect will be the most shielded and subsequently confirmed by theoretical spectra appeared at $164.96 \mathrm{ppm}$. While the rest of the signals are assigned based on anisotropic effects and even by the theoretical data.

On the ${ }^{13} \mathrm{C}$ NMR DEPT 135 spectra (Fig. 4c), we see the disappearance of the peaks relating to the quaternary carbons $\mathrm{C}_{1}, \mathrm{C}_{7}$, and $\mathrm{C}_{8}$, which confirms the structure proposed for our tetraaza macrocyclic ligand.

By comparing the ${ }^{1} \mathrm{H},{ }^{13} \mathrm{C}$ NMR spectra (Fig. 5b) of the iron complex to that of the free ligand (Fig. 4a) a slight variation in chemical shifts was observed, which proves that the complexation of the metal ion has taken place. On the other hand, the multiplicity of peaks has almost disappeared. Indeed, in the spectrum, we find either broad singlets or broad doublets. It is assumed that this broadening of the peaks is caused by the strong field of Fe(II) in its coordination sphere. Indeed, the Fe(II) ion has a low spin, so its behaviour is paramagnetic $[69,70]$. Hence, the resolution of the ${ }^{1} \mathrm{H}$ NMR spectrum is slightly reduced. The ${ }^{13} \mathrm{C}$ NMR spectra are also marked by a change in peak resolution caused by the same phenomenon. The number of peaks in the spectrum confirms the number of carbon atoms in the molecular structure taking into consideration the applied symmetry.

To visualize the phenomenon of paramagnetism, we record the ${ }^{1} \mathrm{H}$ NMR spectrum of the complex $\left[\left(\mathrm{C}_{40} \mathrm{H}_{28} \mathrm{~N}_{4}\right) @ \mathrm{Fe}_{3} \mathrm{O}_{4} \mathrm{NPs}\right]$ (Fig. 6), which is a magnetic material possessing magnetization in the presence of a magnetic field (stronger magnetic field). We can therefore see the absence of all signals from aromatic protons. This is also explained by the greater decrease in spectrum resolution. Slight differences between experimental and theoretical values are essentially due to the model used to be taken into account of solvent effect on the molecule.

Table 3 groups all the ${ }^{1} \mathrm{H}$ and ${ }^{13} \mathrm{C}$ NMR spectral data of the ligand and $\left[\mathrm{Fe}\left(\mathrm{C}_{40} \mathrm{H}_{28} \mathrm{~N}_{4}\right)\right]$ complex and gives the values of the chemical shifts relating to each proton and each carbon of structures. We notice a perfect agreement between the results obtained experimentally and the theoretically and bibliographical data. 
Table 3

Experimental and theoretical calculation NMR of ${ }^{1} \mathrm{H}$ and ${ }^{13} \mathrm{C}$ for (a) ligand $\left(\mathrm{C}_{40} \mathrm{H}_{28} \mathrm{~N}_{4}\right)$, and (b) $\left[\left(\mathrm{C}_{40} \mathrm{H}_{28} \mathrm{~N}_{4}\right) @ \mathrm{Fe}(\mathrm{II})\right]$.

\begin{tabular}{|c|c|c|c|c|c|c|}
\hline \multirow[t]{2}{*}{ Atom } & \multicolumn{3}{|l|}{ (a) } & \multicolumn{3}{|l|}{ (b) } \\
\hline & \multicolumn{2}{|c|}{$\delta_{\operatorname{Exp}}(p p m)$} & $\delta_{\text {Theo }}(\mathrm{ppm})$ & \multicolumn{2}{|c|}{$\delta_{\operatorname{Exp}}(p p m)$} & $\delta_{\text {Theo }}(\mathrm{ppm})$ \\
\hline $\mathrm{H}_{2}$ & \multicolumn{2}{|l|}{7.88} & 7.85 & \multicolumn{2}{|l|}{8.15} & 8.58 \\
\hline $\mathrm{H}_{3}$ & \multicolumn{2}{|l|}{8.15} & 8.18 & \multicolumn{2}{|l|}{7.88} & 7.90 \\
\hline \multirow[t]{2}{*}{$\mathrm{H}_{9}, \mathrm{H}_{10}, \mathrm{H}_{11}, \mathrm{H}_{12}, \mathrm{H}_{13}$} & \multicolumn{2}{|l|}{ 7.3-7.5 } & $7.45-7.90$ & \multicolumn{2}{|c|}{$7.15-7.65$} & 7.73-7.97 \\
\hline & $\delta \mathrm{C}$ & $\delta_{\mathrm{C}}$ DEPT135 & & $\delta C$ & $\delta_{\mathrm{C}}$ DEPT135 & \\
\hline$C_{1}$ & 138.76 & - & 149.40 & 138.75 & - & 138.25 \\
\hline $\mathrm{C}_{2}$ & 128.03 & 128.03 & 130.52 & 128.03 & 128.03 & 129.30 \\
\hline $\mathrm{C}_{3}$ & 128.75 & 128.75 & 131.82 & 128.75 & 128.75 & 133.47 \\
\hline$C_{7}$ & 153.05 & - & 164.96 & 153.04 & - & 160.75 \\
\hline $\mathrm{C}_{8}$ & 140.45 & - & 136.66 & 140.44 & - & 146.73 \\
\hline $\mathrm{C}_{9}$ & 128.80 & 128.80 & 135.50 & 128.79 & 128.79 & 135.65 \\
\hline $\mathrm{C}_{10}$ & 130.40 & 130.40 & 134.94 & 130.39 & 130.39 & 136.19 \\
\hline$C_{11}$ & 129.68 & 129.68 & 139.05 & 129.67 & 129.67 & 135.86 \\
\hline
\end{tabular}

\subsection{IR Spectrum analysis}

The preliminary identification of the Schiff bases macrocyclic ligand and their complexes have been done by the FT-IR. The computed harmonic vibrational wavenumbers were calculated at B3LYP-D3/6-311G (d, p) using scaling factors 0.967, which accounts for systematic errors caused by basis set incompleteness, neglect of electron correlation, and vibrational anharmonicity [71]. The comparative simulated and observed vibrational wavenumbers in the gas phase are gathered in Table 4. The calculated IR spectrum with the experimental FT-IR spectra of all products synthesized (a), (b) and (c) were shown in Fig. 7. We can identify the different vibrations, after calculating the localized modes [72, 73] using the graphical interfaces Gaussview [59].

Regarding the IR spectrum of the ligand $\left(\mathrm{C}_{40} \mathrm{H}_{28} \mathrm{~N}_{4}\right)$, no signals in the range $3200-3390 \mathrm{~cm}^{-1}$ related to an amino group v $\left(\mathrm{NH}_{2}\right)$ or near $1716 \mathrm{~cm}^{-1}$ corresponding to the keto group were observed. This indicates the total formation of condensation of the amino groups with keto groups then an apparition of macrocyclic Schiff's base. The spectrum (a) (Fig. 7) shows the appearance of a weak absorption band in the 3013-3070 $\mathrm{cm}^{-1}$ range corresponding to $\mathrm{CH}_{\text {arom}}$, the computed value of this band is observed in the range of 3064-3104. The appearance of the novel band at $1636 \mathrm{~cm}^{-1}$ is attributable to the characteristic stretching frequencies of the imine linkage $\mathrm{U}(\mathrm{C}=\mathrm{N})$ and this is confirming a good agreement with the theoretical result which appears at $1620 \mathrm{~cm}^{-1}$. In addition, an absorption band is consistently observed at $1443 \mathrm{~cm}^{1}$, this strong intensity band is attributed to the valence absorption of the aromatic $(C=C)$ function. The theoretically calculated values appear in $1427 \mathrm{~cm}^{-1}$. By comparing spectra (b) and (c) corresponds to $\left[\left(\mathrm{C}_{40} \mathrm{H}_{28} \mathrm{~N}_{4}\right) @ \mathrm{Fe}(\mathrm{II})\right] \mathrm{complex}$ and $\left[\left(\mathrm{C}_{40} \mathrm{H}_{28} \mathrm{~N}_{4}\right) @ \mathrm{Fe}_{3} \mathrm{O}_{4} \mathrm{NPs}\right]$ to (a), there is a slight shift in the frequency of the absorption band $(\mathrm{C}=\mathrm{N})$ as well as shown in theoretical spectra (Table 4) which indicate that the nitrogen atom of the imine group is coordinated to the iron. This bathochromic shift can be explained by the increased delocalization of electrons through the newly coordinated metal center.

A new peak in $427 \mathrm{~cm}^{-1}$ appears in the spectra of $\left[\left(\mathrm{C}_{40} \mathrm{H}_{28} \mathrm{~N}_{4}\right) @ \mathrm{Fe}(\mathrm{II})\right]$ complex (b) and the magnetized complex (c) attributed to the $\mathrm{V}$ (Fe-N) vibration corresponding respectively to $430 \mathrm{~cm}^{-1}$ and $420 \mathrm{~cm}^{-1}$ in the theoretical spectra. However, the vibration band $\mathrm{v}$ ( $\mathrm{Fe}-\mathrm{O}$ ) appears at $479 \mathrm{~cm}^{-1}$ attributable to $448 \mathrm{~cm}^{-1}$ theoretically. It is a week and broadband, which confirm the formation of $\mathrm{Fe}_{3} \mathrm{O}_{4} \mathrm{NPs}$ in-situ of the macrocycle. The comparison of the vibrational frequencies calculated at $6-311 \mathrm{G}(\mathrm{d}, \mathrm{p})$ basis set gives reasonable deviations from the experimental values. 
Figure 7 Comparison of experimental and theoretical FT-IR of (a) ligand $\left(\mathrm{C}_{40} \mathrm{H}_{28} \mathrm{~N}_{4}\right)$, (b) $\left[\left(\mathrm{C}_{40} \mathrm{H}_{28} \mathrm{~N}_{4}\right) @ \mathrm{Fe}(\mathrm{II})\right]$ and (c) $\left[\left(\mathrm{C}_{40} \mathrm{H}_{28} \mathrm{~N}_{4}\right) @ \mathrm{Fe}_{3} \mathrm{O}_{4} \mathrm{NPs}\right]$.

Table 4

The principals of vibration bands synthesized structures are presented in the table below.

\begin{tabular}{|c|c|c|c|c|c|c|c|c|c|c|c|}
\hline (a) & & & & (b) & & & & (c) & & & \\
\hline $\begin{array}{l}\mathbf{v}_{\text {calc }} \\
\text { Unscaled }\end{array}$ & $\begin{array}{l}\mathbf{v}_{\text {calc }} \\
\text { Scaled }^{\mathrm{a}}\end{array}$ & $v_{\text {Exp }}$ & Vibration & $\begin{array}{l}\mathbf{v}_{\text {calc }} \\
\text { Unscaled }\end{array}$ & $\begin{array}{l}\mathrm{v}_{\text {calc }} \\
\text { Scaled }^{\mathrm{a}}\end{array}$ & $v_{\text {Exp }}$ & Vibration & $\begin{array}{l}\mathrm{v}_{\text {calc }} \\
\text { Unscaled }\end{array}$ & $\begin{array}{l}\mathbf{v}_{\text {calc }} \\
\text { Scaled }^{a}\end{array}$ & $v_{\text {Exp }}$ & Vibration \\
\hline - & - & - & - & 445 & 430 & 427 & $\mathrm{Fe}-\mathrm{N}$ & 434 & 420 & 427 & $\mathrm{Fe}-\mathrm{N}$ \\
\hline- & - & - & - & - & - & - & - & 463 & 448 & 479 & $\mathrm{Fe}-\mathrm{O}$ \\
\hline 596 & 576 & 598 & $\begin{array}{l}\mathrm{CH} \\
\text { Oopb+ } \\
\mathrm{CN} \mathrm{b}\end{array}$ & 609 & 589 & 597 & $\begin{array}{l}\mathrm{CH} \\
\text { oopb+ } \\
\mathrm{CN} \mathrm{b}\end{array}$ & 669 & 646 & 603 & $\begin{array}{l}\mathrm{CH} \\
\text { oopb+ } \\
\mathrm{CN} \mathrm{b}+ \\
\mathrm{CC} \mathrm{b}\end{array}$ \\
\hline 706 & 683 & 696 & $\mathrm{CH}$ oopb & 711 & 688 & 698 & $\mathrm{CH}$ oopb & 723 & 699 & 697 & $\begin{array}{l}\mathrm{CH} \\
\text { Oopb+ } \\
\mathrm{CN} \mathrm{b}\end{array}$ \\
\hline 779 & 753 & 771 & $\mathrm{CH}$ oopb & 805 & 778 & 770 & $\mathrm{CH}$ oopb & 769 & 743 & 765 & $\mathrm{CH}$ oopb \\
\hline 932 & 901 & 976 & $\begin{array}{l}\mathrm{CH} \\
\text { OOpb+ } \\
\mathrm{CN} \mathrm{b}\end{array}$ & 981 & 949 & 976 & $\begin{array}{l}\mathrm{Fe}-\mathrm{N}+ \\
\mathrm{CN} \text { b+ } \\
\mathrm{CH} \text { oopb }\end{array}$ & 993 & 960 & 978 & $\begin{array}{l}\text { Fe-N+ } \\
\mathrm{CC} \mathrm{b+} \\
\mathrm{CN} \mathrm{b}+ \\
\mathrm{CH} \text { oopb }\end{array}$ \\
\hline 1363 & 1318 & 1347 & $\begin{array}{l}\mathrm{CC} \text { str+ } \\
\mathrm{CN}+\mathrm{CH} \\
\mathrm{ipb}\end{array}$ & 1361 & 1316 & 1346 & $\begin{array}{l}\mathrm{CC} \text { str+ } \\
\mathrm{CN}+\mathrm{CH} \\
\text { ipb }\end{array}$ & 1340 & 1295 & 1346 & $\begin{array}{l}\mathrm{CH} \\
\text { benzene } \\
+\mathrm{CC} \\
\text { str+CH } \\
\text { ipb+CN } \\
\text { str }\end{array}$ \\
\hline 1476 & 1427 & 1443 & $\begin{array}{l}\text { CC str+ } \\
\text { CH ipb }\end{array}$ & 1511 & 1461 & 1443 & $\begin{array}{l}\text { CC str+ } \\
\text { CH ipb }\end{array}$ & 1442 & 1394 & 1443 & $\begin{array}{l}\text { CC str+ } \\
\mathrm{CH} \text { ipb+ }\end{array}$ \\
\hline 1675 & 1620 & 1636 & $\begin{array}{l}\mathrm{CC} \mathrm{b+} \\
\mathrm{CN} \text { str + } \\
\mathrm{CH} \text { ipb }\end{array}$ & 1640 & 1586 & 1638 & $\begin{array}{l}\text { CC strt } \\
\text { CN str+ } \\
\text { CH ipb }\end{array}$ & 1532 & 1481 & 1638 & $\begin{array}{l}\text { CN strt } \\
\text { CC str+ } \\
\text { CH ipb }\end{array}$ \\
\hline $\begin{array}{l}3169- \\
3210\end{array}$ & $\begin{array}{l}3064- \\
3104\end{array}$ & $\begin{array}{l}3013- \\
3070\end{array}$ & $\mathrm{CH}_{\text {arom }}$ & $\begin{array}{l}3165- \\
3200\end{array}$ & $\begin{array}{l}3061- \\
3094\end{array}$ & $\begin{array}{l}3013- \\
3070\end{array}$ & $\mathrm{CH}_{\text {arom }}$ & $\begin{array}{l}3112- \\
3228\end{array}$ & $\begin{array}{l}3009- \\
3121\end{array}$ & $\begin{array}{l}3013- \\
3070\end{array}$ & $\mathrm{CH}_{\text {arom }}$ \\
\hline
\end{tabular}

\subsection{Photophysical properties}

\subsubsection{Absorption properties}

The electronic spectrum of the Schiff base ligand (a), complexes (b), and (c) was recorded in DMSO theoretically as well as experimentally. The calculated absorption spectra were done by the TD-DFT method at CAM-B3LYP-D3/6-311G (d, p) level of basis set. These spectra are shown in Fig. 8 and their wavelengths $\left(\lambda_{\operatorname{Exp}}\right.$ and $\left.\lambda_{\text {Cal }}(\mathrm{nm})\right)$, oscillator strength (f) and (\%) contribution from each transition are given in Table 5 As shown in Fig. 8, all the compounds (a), (b) and (c) exhibit only one broadband ranging from 311 to 390 $\mathrm{nm}$ for the experimental spectra and from 361 to $346 \mathrm{~nm}$ for the theoretical spectra attributed to the $n-\pi^{\star}$ transitions of the $C=N$ and $C=C$ bands.

By comparing the spectra of the $\left[\left(\mathrm{C}_{40} \mathrm{H}_{28} \mathrm{~N}_{4}\right) @ \mathrm{Fe}(\mathrm{II})\right]$ and $\left[\left(\mathrm{C}_{40} \mathrm{H}_{28} \mathrm{~N}_{4}\right) @ \mathrm{Fe}_{3} \mathrm{O}_{4} \mathrm{NPs}\right]$ complexes with that of the free ligand, we observe practically the same shape with a slight shift of $\lambda_{\max }$ observed at (344 and $339 \mathrm{~nm}$ ) and at ( 355 and $346 \mathrm{~nm}$ ) for the experimental and theoretical spectra respectively due to the complexation and polarization of the $(\mathrm{C}=\mathrm{N})$ bond by the metal-ligand interaction. The 
absence of bands relating to ligand-metal charge transfer phenomena (LMCT) and the $\mathrm{d}$-d transition is probably due to the low solubility of the complexes in the solvent DMSO $[74,75]$.

Table 5

Detailed parameters of UV-Vis of (a) ligand $\left(\mathrm{C}_{40} \mathrm{H}_{28} \mathrm{~N}_{4}\right)$, (b) $\left[\left(\mathrm{C}_{40} \mathrm{H}_{28} \mathrm{~N}_{4}\right) @ \mathrm{Fe}(\mathrm{II})\right]$, and (c) $\left[\left(\mathrm{C}_{40} \mathrm{H}_{28} \mathrm{~N}_{4}\right) @ \mathrm{Fe}_{3} \mathrm{O}_{4} \mathrm{NPs}\right]$.

\begin{tabular}{|c|c|c|c|c|}
\hline & $\lambda_{\operatorname{Exp}}(\mathrm{nm})$ & $\begin{array}{l}\lambda_{\mathrm{Cal}} \\
(\mathrm{nm})\end{array}$ & $f(a, u)$ & Transition configuration coefficient \\
\hline \multirow[t]{3}{*}{ (a) } & 345 & 361 & 0.216 & $\mathrm{H}-4 \rightarrow \mathrm{L}(43 \%)$ \\
\hline & & & & $\mathrm{H}-5 \rightarrow \mathrm{L}(29 \%)$ \\
\hline & & & & $H \rightarrow L+2(13 \%)$ \\
\hline \multirow[t]{3}{*}{ (b) } & 344 & 355 & 0.198 & $H \rightarrow L+2(58 \%)$ \\
\hline & & & & $\mathrm{H}-4 \rightarrow \mathrm{L}+1(22 \%)$ \\
\hline & & & & $\mathrm{H}-2 \rightarrow \mathrm{L}+1(10 \%)$ \\
\hline \multirow[t]{3}{*}{ (c) } & 339 & 346 & 0.202 & $\mathrm{H} \rightarrow \mathrm{L}+1(64 \%)$ \\
\hline & & & & $H-1 \rightarrow L+2(14 \%)$ \\
\hline & & & & $\mathrm{H}-3 \rightarrow \mathrm{L}(12 \%)$ \\
\hline
\end{tabular}

\subsubsection{Frontier molecular orbital analysis}

The highest occupied molecular orbital (HOMO) and the lowest unoccupied molecular orbital (LUMO) are named frontier molecular orbitals (FMOs) and they are a very important parameter for quantum chemistry [76]. The FMOs energy, the electronic chemical potential $(\mu)$, the chemical hardness $(\eta)$, the global softness $(\sigma)$ and the dipole moment $\left(\mu_{\mathrm{D}}\right)$ for (a) ligand, $(\mathbf{b})\left[\left(\mathrm{C}_{40} \mathrm{H}_{28} \mathrm{~N}_{4}\right) @ \mathrm{Fe}(\mathrm{II})\right]$ and (c) $\left[\left(\mathrm{C}_{40} \mathrm{H}_{28} \mathrm{~N}_{4}\right) @ \mathrm{Fe}_{3} \mathrm{O}_{4} \mathrm{NPs}\right]$ are given in Table 6. The computations were done by the CAM-B3LYP-D3/6-311G (d, p) level. These values serve to exemplify the kinetic stability of the molecule and the chemical reactivity [77]. It should be indicated that the change in bandgap brings about variations in conductivity. The relationship between conductivity and energy bandgap $\left(E_{g}\right)$ can be estimated using the following equation [78]:

$\sigma \propto-\exp \left(-\mathrm{Eg} / \mathrm{K}_{\mathrm{B}} \mathrm{T}\right)(2)$

Here, $\sigma$ is the electric conductivity and $\mathrm{K}_{\mathrm{B}}$ denotes the Boltzmann constant. It is conspicuous that a small decrease in the bandgap results in a significantly higher electrical conductivity.

As shown in Table 6, the hard molecule, with a large gap, correspond to molecule (a) (3.167 eV), where their electron density changed more hardly than a soft molecule[78]. The small HOMO-LUMO energy gap corresponds to compound (b) (1.484 eV) which means small excitation energies. Thus, the HOMO-LUMO gaps decrease by about 1.683 and $1.368 \mathrm{eV}$ for (b) and (c) respectively. The low value of the energy gap of these two molecules especially for $(\mathbf{b})$ is due to electron-with drawing groups that enter into conjugation.

Furthermore, the electronic chemical potential and the chemical hardness were slightly reduced under the complexation with the metallic center $\mathrm{Fe}$ and the $\mathrm{Fe}_{3} \mathrm{O}_{4}$. The global softness of (a) increase from $0.631 \mathrm{eV}^{-1}$ to 1.348 and $1.111 \mathrm{eV}^{-1}$ for (b) and (c) respectively. Based on these quantum chemical parameters, we are able to estimate the geometry of molecules and to provide not only the electronic parameters but also to extract information about the reactivity and selectivity of the compounds. Consequently, we can notice that the complexation of ligand (a) with the metallic center Fe then with the $\mathrm{Fe}_{3} \mathrm{O}_{4}$ affects the stability and the reactivity of this molecule, where (b) and (c) present low chemical stability and they have high reactivity than (a) respectively. It also implies that after the addition of the metallic center $\mathrm{Fe}$ in the tetraaza macrocyclic cavity of the ligand, the molecule (b) become more conductive, more polarizable, and softer (with lower molecular stability and high reactivity in chemical reactions) because it needs small energy to excitation compared to (a) and (c) respectively and it is thermodynamically favourable for an electron transfer to occur.

Moreover, the frontier molecular orbitals of (a), (b) and (c) in DMSO solvent were shown in Fig. 9. The HOMO represents the ability to donate an electron and the LUMO as electron acceptor represents the ability to obtain an electron. The positive and negative phases are 
given in red and green, respectively $[78,79]$. It can be seen from this figure, that the HOMO of molecule (a) is localized mainly on the tetraaza macrocyclic ligand and on the 1,2 substituted benzene while the LUMO is localized extensively over the whole molecule. It is also clear from Figure that the two compounds (b), and (c) give similar HOMO orbital which is localized on the 1,2 substituted benzene and on the tetraaza macrocyclic cavity with a large electronic density on $\mathrm{Fe}-\mathrm{N}$ bond for the molecule (b) further, the electron density is located around the $\mathrm{Fe}_{3} \mathrm{O}_{4}$ for the molecule (c). We can observe that there is an electron density transfer between the tetraaza macrocyclic ligand and the metallic center $\mathrm{Fe}$ (for (b)) and $\mathrm{Fe}_{3} \mathrm{O}_{4}$ (for (c)). For the LUMO orbital of these molecules, there is no significant change for the delocalization of HOMO. The qualitative picture proves a flow of electron density (intramolecular charge transfer) from the electrondonor groups byway of the $\pi$-electron bridge to the electron acceptor groups.

Table 6

The calculated electronic and quantum chemical parameters for (a), (b) and (c) computed at DFT/B3LYP-D3/6-311 G (d, p).

\begin{tabular}{|llllllll|}
\hline & $\begin{array}{l}\text { HOMO } \\
(\mathrm{eV})\end{array}$ & $\begin{array}{l}\text { LUMO } \\
(\mathrm{eV})\end{array}$ & $\mathrm{E}_{\mathrm{g}}(\mathrm{eV})$ & $\boldsymbol{\mu}(\mathrm{eV})$ & $\boldsymbol{\eta}(\mathrm{eV})$ & $\sigma(\mathrm{eV})^{-1}$ & $\mu_{\mathrm{D}}(\mathrm{D})$ \\
\hline (a) & -5.389 & -2.222 & 3.167 & 3.806 & 1.584 & 0.631 & 2.206 \\
\hline (b) & -4.305 & -2.821 & 1.484 & 3.563 & 0.742 & 1.348 & 1.370 \\
\hline (c) & -4.652 & -2.852 & 1.799 & 3.752 & 0.900 & 1.111 & 5.379 \\
\hline
\end{tabular}

\subsection{Scanning electron microscopic (SEM) and EDX analysis}

The Scanning Electron Microscope (SEM) was recorded to observe the morphology of products synthesized. As shown in Fig. 10a the images of the macrocyclic $\left(\mathrm{C}_{40} \mathrm{H}_{28} \mathrm{~N}_{4}\right)$ taken at different resolutions showed a crystal morphology in form of column crystal.

The SEM micrograph of the complex (Fig. 10b) displayed also the formation of crystals whose metal is clearly attached within the tetraaza macrocycle cavity.

Chemical co-precipitation was widely applied to prepare high-quality iron oxide nanoparticles, but it is very difficult to obtain uniform iron oxide nanoparticles in an aqueous solution $[19,80]$. The shape, size, and surface morphology of magnetite NPs have been studied previously $[31,81]$. Nevertheless, the synthesis of uniform NPs of the same size remains a bit difficult and this is one of the objectives of our work.

As shown in Fig. 10c, it was possible to form dispersed nanoparticles with regular spherical shape by the method of germination that encapsulated in the tetraaza cavity of the macrocyclic ligand. This encapsulation allowed the dispersion of the nanoparticles on the surface of the material by reducing the dipole-dipole magnetic interactions. The diameter of the nanoparticles was determined from the SEM image (Fig. 10c), their average size was approximately between $11 \mathrm{~nm}$, and $50 \mathrm{~nm}$, this result is in perfect agreement with the result found by DRX.

The EDX analysis revealed atomic content of samples synthetized which confirmed the presence of all constituent atoms: carbon (C), nitrogen $(\mathrm{N})$ in the ligand $\left(\mathrm{C}_{40} \mathrm{H}_{28} \mathrm{~N}_{4}\right)$ in Fig. 11a. In addition to these elements, iron complex contained iron (Fe) in Fig. 11b, while in the case of magnetite $\left(\mathrm{Fe}_{3} \mathrm{O}_{4}\right) \mathrm{NPs}$ incorporated in the macrocyclic confirmed the presence of carbon (C), nitrogen ( $\left.\mathrm{N}\right)$, iron $(\mathrm{Fe})$ and oxygen (0) in Fig. 11c.

However, detected elements in the EDX data indicate that all samples were successfully synthesized[82].

Table 7 groups all the EDX data of (a) ligand $\left(\mathrm{C}_{40} \mathrm{H}_{28} \mathrm{~N}_{4}\right)$, (b) $\left[\left(\mathrm{C}_{40} \mathrm{H}_{28} \mathrm{~N}_{4}\right) @ \mathrm{Fe}(\mathrm{II})\right]$ and (c) $\left[\left(\mathrm{C}_{40} \mathrm{H}_{28} \mathrm{~N}_{4}\right) @ \mathrm{Fe}_{3} \mathrm{O}_{4} \mathrm{NPs}\right]$ complex. 
Table 7

EDX data of (a) ligand $\left(\mathrm{C}_{40} \mathrm{H}_{28} \mathrm{~N}_{4}\right),(\mathrm{b})\left[\left(\mathrm{C}_{40} \mathrm{H}_{28} \mathrm{~N}_{4}\right) @ \mathrm{Fe}(\mathrm{II})\right]$ and (c) $\left[\left(\mathrm{C}_{40} \mathrm{H}_{28} \mathrm{~N}_{4}\right) @ \mathrm{Fe}_{3} \mathrm{O}_{4} \mathrm{NPs}\right]$ complex.

\begin{tabular}{|lllll|}
\hline Compound & \multicolumn{4}{l|}{ Elemental analysis (\%) found (Calcd.) } \\
\cline { 2 - 5 } & $\mathrm{C}$ & $\mathrm{N}$ & $\mathbf{0}$ & $\mathrm{Fe}$ \\
\hline$\left(\mathrm{C}_{40} \mathrm{H}_{28} \mathrm{~N}_{4}\right){ }^{\text {(a) }}$ & $85.28(87.11)$ & $14.72(12.89)$ & - & - \\
\hline$\left[\left(\mathrm{C}_{40} \mathrm{H}_{28} \mathrm{~N}_{4}\right) @ \mathrm{Fe}(\mathrm{II})\right]^{(b)}$ & $81.86(85.69)$ & $15.21(13.65)$ & - & $2.93(0.66)$ \\
\hline$\left[\left(\mathrm{C}_{40} \mathrm{H}_{28} \mathrm{~N}_{4}\right) @ \mathrm{Fe}_{3} \mathrm{O}_{4} \mathrm{NPs}\right]^{(\mathrm{c})}$ & $47.13(67.77)$ & $3.58(4.41)$ & $16.32(17.62)$ & $32.97(10.20)$ \\
\hline
\end{tabular}

Table 8 presents the value of average size of magnetite nanoparticles found in this work by XRD and SEM pictures by comparing with literature. According to these references, the synthesis of nanoparticles encapsulated inside tetraaza macrocycle with sizes between 11 and $50 \mathrm{~nm}$ is well controlled.

\subsection{Thermogravimetric studies}

Table 8

Comparison between size of magnetite nanoparticles in this work with litterature

\begin{tabular}{|llll|}
\hline \multirow{2}{*}{ Sample } & \multicolumn{3}{l|}{$\mathrm{Fe}_{3} \mathrm{O}_{4}$ NPs Size $(\mathrm{nm})$} \\
\cline { 2 - 4 } & $\mathrm{XRD}(\mathrm{FWHM})$ & SEM & Ref. \\
\hline$\left[\left(\mathrm{C}_{40} \mathrm{H}_{28} \mathrm{~N}_{4}\right) @ \mathrm{Fe}_{3} \mathrm{O}_{4} \mathrm{NPs}\right]$ & 11 & $11-50$ & {$[83,84]$} \\
\hline
\end{tabular}

The TGA curves of the ligand $\left(\mathrm{C}_{40} \mathrm{H}_{28} \mathrm{~N}_{4}\right)$ and of the $\left[\left(\mathrm{C}_{40} \mathrm{H}_{28} \mathrm{~N}_{4}\right) @ \mathrm{Fe}_{3} \mathrm{O}_{4} \mathrm{NPs}\right]$ are shown in Fig. 12 below:

Thermograms of TGA of macrocyclic $\left(\mathrm{C}_{40} \mathrm{H}_{28} \mathrm{~N}_{4}\right)$ and $\left[\left(\mathrm{C}_{40} \mathrm{H}_{28} \mathrm{~N}_{4}\right) @ \mathrm{Fe}_{3} \mathrm{O}_{4} \mathrm{NPs}\right]$ show that no weight loss was observed before $150^{\circ} \mathrm{C}$. First, the TGA thermogram of the ligand $\left(\mathrm{C}_{40} \mathrm{H}_{28} \mathrm{~N}_{4}\right)$ shows an obvious weight loss of $100 \%$ between $142^{\circ} \mathrm{C}$ to $250^{\circ} \mathrm{C}$ corresponds to the total melting and decomposition of macrocyclic. Second, the TGA thermogram of $\left[\left(\mathrm{C}_{40} \mathrm{H}_{28} \mathrm{~N}_{4}\right) @ \mathrm{Fe}_{3} \mathrm{O}_{4} \mathrm{NPs}\right]$ has three stages of thermal degradation. An estimated initial weight loss of 25 in mass, which occurs due to the fractionation and total degradation of organic material in $\left[\left(\mathrm{C}_{40} \mathrm{H}_{28} \mathrm{~N}_{4}\right) @ \mathrm{Fe}_{3} \mathrm{O}_{4} \mathrm{NPs}\right]$. From $310^{\circ} \mathrm{C}$, only the mineral matter remains in the form of magnetite $\mathrm{Fe}_{3} \mathrm{O}_{4}$ nanoparticles, very resistant to heat and estimated at $64 \%$ of the total weight of the sample.

These results confirm Furthermore that the $\mathrm{Fe}_{3} \mathrm{O}_{4} \mathrm{NPs}$ have been successfully encapsulated in the macrocyclic tetraaza concavity and that the $\mathrm{Fe}_{3} \mathrm{O}_{4}$ weight content is about $64 \%$ and the density is about $25 \mathrm{mmol} . \mathrm{g}^{-1}$.

\subsection{Magnetic properties measurement}

Some nanoparticles have been characterized not only by their size distribution, shape, and surface chemistry. but also, they are clearly known by their magnetic properties $[85,86]$. Obviously, the iron element $(\mathrm{Fe})$ has a strong magnetic moment due to the four unpaired electrons in its $3 \mathrm{~d}$ orbitals. So, when crystals such as magnetite $\left(\mathrm{Fe}_{3} \mathrm{O}_{4}\right)$ are formed from iron cations, different magnetic states can occur and this will be revealed by measuring magnetic properties.

Vibrating Sample Magnetometry (VSM) has been used to study the magnetic properties of $\left[\left(\mathrm{C}_{40} \mathrm{H}_{28} \mathrm{~N}_{4}\right) @ \mathrm{Fe}_{3} \mathrm{O}_{4} \mathrm{NPs}\right]$ by measuring the magnetic-hysteresis at $300 \mathrm{~K}$ temperature and the thermomagnetic curve depending on temperature between $120 \mathrm{~K}$ and $300 \mathrm{~K}$.

Figure 13a presents the magnetic hysteresis loop analysis based on the relationship between magnetization (M) versus Magnetic field $(\mathrm{H})$ that shows a similar shape compared to free $\mathrm{Fe}_{3} \mathrm{O}_{4} \mathrm{NPs}$ by returning to literature [87, 88]. So the ferromagnetic character of $\left[\left(\mathrm{C}_{40} \mathrm{H}_{28} \mathrm{~N}_{4}\right) @ \mathrm{Fe}_{3} \mathrm{O}_{4} \mathrm{NPs}\right]$ was proved and the magnetite $\mathrm{Fe}_{3} \mathrm{O}_{4}$ was successfully incorporated inside the macrocycle due to the significant decrease of the saturated magnetization $\left(\mathrm{M}_{\mathrm{s}}\right)$ from $(57.33 \mathrm{emu} / \mathrm{g}$ ) [47] of magnetite to $35 \mathrm{emu} / \mathrm{g}$ suggesting that the tetraaza macrocyclic ligand reduced the magnetic response to an applied magnetic field. In addition, this decrement can be explained either by the change of structure and/or by the surface anisotropy upon coating [89]. 
The coercivity $\left(H_{C}\right)$ and remnant magnetization $\left(M_{r}\right)$, and squareness $\left(S_{r}=M_{r} / M_{s}\right)$ were calculated and listed in Table 9 . Hence the remnant magnetization was found to be $22.4 \mathrm{emu} / \mathrm{g}$ whereas the coercive field $\left(\mathrm{H}_{\mathrm{C}}\right)$ attained $0.11 \mathrm{~T}$. the very small variation of remanence ratio value $\mathrm{S}_{\mathrm{r}}$ of $\mathrm{Fe}_{3} \mathrm{O}_{4} \mathrm{NPs}$ coated can be ascribed to interparticle and intraparticle interactions [90].

The zero-field cold (ZFC) and the field cooling (FC) measurements were carried out on the $\left[\left(\mathrm{C}_{40} \mathrm{H}_{28} \mathrm{~N}_{4}\right) @ F e_{3} \mathrm{O}_{4} \mathrm{NPs}\right]$ to better understand the magnetic properties (Fig. 13b).

In the FC measurement case, each particle magnetization direction is sheltered while the ZFC net magnetization is zero. In addition, a random distortion characterizes the resulted magnetic spins. Furthermore, the ZFC typically decreased in the case of nanoparticles. In contrast, FC increased along with the temperature decrease. In fact, heating the sample induced the ZFC magnetization which consequently increase and approach the ZFC value to a blocking temperature. The aforementioned temperature characterized the domain's orientation. The homogenous particle size is characterized by an abrupt charge distribution. In the ZFC curve, the maximum value occurred above $302 \mathrm{~K}$ (Fig. 13b). The high blocking temperature qualifies a large particle size as well as the particle's magnetic interaction. The ZFC curve of the $\left[\left(\mathrm{C}_{40} \mathrm{H}_{28} \mathrm{~N}_{4}\right) @ \mathrm{Fe}_{3} \mathrm{O}_{4} \mathrm{NPs}\right]$ decreased and approached zero along with temperature decrease. However, the $\mathrm{FC}$ curve of the $\left[\left(\mathrm{C}_{40} \mathrm{H}_{28} \mathrm{~N}_{4}\right) @ \mathrm{Fe}_{3} \mathrm{O}_{4} \mathrm{NPs}\right]$ decreases slightly when the temperature increases. Both $\mathrm{FC}$ and ZFC curves of $\left[\left(\mathrm{C}_{40} \mathrm{H}_{28} \mathrm{~N}_{4}\right) @ \mathrm{Fe}_{3} \mathrm{O}_{4} \mathrm{NPs}\right]$ followed a similar trend.

Table 9

Magnetic properties of the $\left[\left(\mathrm{C}_{40} \mathrm{H}_{28} \mathrm{~N}_{4}\right) @ \mathrm{Fe}_{3} \mathrm{O}_{4} \mathrm{NPs}\right]$.

\begin{tabular}{|llllll|}
\hline Sample & $\mathrm{T}_{\mathrm{b}}(\mathrm{K})$ & $\mathrm{H}_{\mathrm{C}}(\mathrm{T})$ & $\mathrm{M}_{\mathrm{s}}(\mathrm{emu} / \mathrm{g})$ & $\mathrm{M}_{\mathrm{r}}(\mathrm{emu} / \mathrm{g})$ & $\mathrm{S}_{\mathrm{r}}$ \\
& & $(\mathrm{M}=0)$ & $(\mathrm{H}=0.01 \mathrm{~T})$ & & \\
\hline$\left[\left(\mathrm{C}_{40} \mathrm{H}_{28} \mathrm{~N}_{4}\right) @ \mathrm{Fe}_{3} \mathrm{O}_{4} \mathrm{NPs}\right]$ & 302 & 0.11 & 35 & 22.4 & 0.64 \\
\hline
\end{tabular}

\section{Conclusion}

To sum up, we have successfully synthesized a tetraaza macrocyclic ligand and its corresponding iron (II) complex. $\mathrm{Besides} \mathrm{Fe}_{3} \mathrm{O}_{4} \mathrm{NPs}$ were fabricated inside the tetraaza macrocyclic ligand by the co-precipitation method. All the synthesized compounds were characterized by physic-chemical techniques like XRD, NMR, FT-IR, UV-VISIBLE, SEM, EDX, TGA, and VSM. To identify exactly the structures developed, we used ${ }^{1} \mathrm{H}$ NMR and ${ }^{13} \mathrm{C}$ NMR spectroscopy that confirmed the structure of the ligand and its metal complex. FTIR spectroscopy essentially showed the characteristic bands of all functions present in the macrocyclic ligand and the effect of complexation on the band of the $\mathrm{C}=\mathrm{N}$ function. Then, UV-Vis spectroscopy allowed us to determine the characteristic $\pi-\pi^{\star}$ absorption band of the ligand attributed to the bonds $(\mathrm{C}=\mathrm{N})$ and $(\mathrm{C}=\mathrm{C})$. The energy gap of $(\mathrm{a}),(\mathrm{b})$ and $(\mathrm{c})$ were $3.167,1.484$ and $1.799 \mathrm{eV}$ respectively, which indicate that the (b) compound was the most conductive (with high reactivity in chemical reactions and lower molecular stability) and belong to soft material. All these properties of the mentioned compound were compared to the calculated spectra using the B3LYP-D3 and CAMB3LYP-D3 /6-311 G (d, p) method, where the theoretical studies showed good agreement with experimental results. Thermogravimetric analysis showed that magnetite nanoparticle weight density was about $25 \mathrm{mmol} / \mathrm{g}$. We were also able to identify some crystallographic properties of the magnetite complex $\left[\left(\mathrm{C}_{40} \mathrm{H}_{28} \mathrm{~N}_{4}\right) @ \mathrm{Fe}_{3} \mathrm{O}_{4} \mathrm{NPs}\right]$ by the X-ray powder diffraction (DRX) method and determine the average size of the magnetite nanoparticles which is approximately $11 \mathrm{~nm}$. This last contribution affirmed a good dispersion and encapsulation of the nanoparticles of magnetite inside the tetraaza macrocycle. This valuable product will be used in the future either by a catalytic application or by a biological application.

\section{Declarations}

\section{ACKNOWLEDGEMENTS}

The authors greatly acknowledge financial support between cooperation Tunisian-Morocco Recherche Programme for funding the work through the research group $\mathrm{N}^{\circ} 17 / \mathrm{TM} 10$.

\section{AUTHOR CONTRIBUTIONS}


Sarah Ben Haj Fraj: Conceptualization; writing original draft. Marwa Chaabene: Conceptualization, data curation, software. Soumaya Agren: Conceptualization, data curation, software. Jamal El Haskouri: Formal analysis, validation. Rafik Ben Chaâbane: investigation, visualization. Mohammed Lahcini: Funding acquisition, writing original draft. Mohamed Hassen V Baouab: Methodology, project admiration, supervision.

\section{CONFLICT OF INTEREST}

The authors declare that they have no conflict of interest.

\section{DATA AVAILABILITY STATEMENT}

The data that support the findings of this study are available upon request from the corresponding author. The data are not publicly available because of privacy/ethical restrictions

\section{ORCID}

Sarah Ben Haj Fraj https://orcid.org/0000-0003-0424-7900

Marwa Chaabene https://orcid.org/0000-0002-0014-6777

Soumaya Agren https://orcid.org/0000-0003-4060-1217

Jamal El Haskourihttps://orcid.org/0000-0002-8895-1681

Mohammed Lahcini https://orcid.org/0000-0003-1049-7906

Rafik Ben Chaâbane https://orcid.org/0000-0001-7605-891X

Mohamed Hassen V Baouab https://orcid.org/0000- 0003-2069-7151

\section{References}

1. E.C. Judkins, M. Zeller, T. Ren, Inorg. Chem. 57, 2249 (2018)

2. N. Sharma, D. Kumar, R. Shrivastava, S. Shrivastava, K.K. Awasthi, (2021)

3. R. Gautam, C. Singh, D.P. Rao, Cis-Dioxomolybdenum (VI) Complexes with N-Donor Macrocyclic Ligands (2021)

4. L. Dey, S. Rabi, D. Palit, S.K.S. Hazari, Z.A. Begum, I.M.M. Rahman, T.G. Roy, J. Mol. Struct. 1240, 130579 (2021)

5. K.C. Gupta, A. Kumar, Sutar, C.-C. Lin, Coord. Chem. Rev. 253, 1926 (2009)

6. A.-N.M.A. Alaghaz, B.A. El-Sayed, A.A. El-Henawy, R.A.A. Ammar, J. Mol. Struct. 1035, 83 (2013)

7. A. Geersing, N. Ségaud, M.G.P. van der Wijst, M.G. Rots, G. Roelfes, Inorg. Chem. 57, 7748 (2018)

8. P.B. Tsitovich, F. Gendron, A.Y. Nazarenko, B.N. Livesay, A.P. Lopez, M.P. Shores, J. Autschbach, J.R. Morrow, Inorg. Chem. 57, 8364 (2018)

9. P. Rajakkani, A. Alagarraj, S.A. Gurusamy, Thangavelu, Inorg. Chem. Commun. 134, 108989 (2021)

10. Z. Li, Y.-W. Yang, Advanced Materials n/a, 2107401 (n.d.)

11. R. Kothari, A. Agrawal, Rasayan J. Chem. 13, 1672 (2020)

12. S. Ch, ra, and P. Pipil, Journal of Chemical and Pharmaceutical Research 5, (2013)

13. Z. Parsaee, K. Mohammadi, J. Mol. Struct. 1137, 512 (2017)

14. X. He, Y. Xue, C.-C. Li, Y. Wang, H. Jiang, L. Zhao, Chem. Sci. 9, 1481 (2018)

15. K. Shalabi, O.A. El-Gammal, Y.M. Abdallah, Colloids Surf., A 609, 125653 (2021)

16. M. Shakir, N. Bano, M.A. Rauf, M. Owais, J. Chem. Sci. 129, 1905 (2017)

17. S. Shreaz, R.A. Shiekh, V. Raja, W.A. Wani, J.M. Behbehani, Chem. Biol. Interact. 247, 64 (2016)

18. G.B. Bagihalli, P.G. Avaji, S.A. Patil, P.S. Badami, Eur. J. Med. Chem. 43, 2639 (2008)

19. L. Chaabane, H. Chahdoura, W. Moslah, M. Snoussi, E. Beyou, M. Lahcini, N. Srairi-Abid, M.H.V. Baouab, Appl. Organomet. Chem. 33, e4860 (2019) 
20. P. Reddy, K. Shanker, Dr.R. Rondla, V. Ravinder, International Journal of ChemTech Research 1, (2009)

21. P.M. Reddy, R. Rohini, E.R. Krishna, A. Hu, V. Ravinder, Int. J. Mol. Sci. 13, 4982 (2012)

22. T. Aiyelabola, J. Jordaan, D. Otto, E. Akinkunmi, Advances in Biological Chemistry 11, 79 (2021)

23. G. Kumar, S. Devi, R. Johari, D. Kumar, Eur. J. Med. Chem. 52, 269 (2012)

24. A. Kulkarni, S.A. Patil, P.S. Badami, Eur. J. Med. Chem. 44, 2904 (2009)

25. V. Sangwan, D.P. Singh, Mater Sci Eng C Mater Biol Appl 105, 110119 (2019)

26. H.A. El-Boraey and O. A. EL-Gammal, Open Chemistry Journal 5, (2018)

27. A. Beheshti, M. Bahrani Pour, M. Kolahi, E. Shakerzadeh, H. Motamedi, P. Mayer, Applied Organometallic Chemistry 35, (2021)

28. N.Joseph Singh, L. Herojit Singh, V.K. Garg, in Nanostructured Materials and Their Applications, edited by B. P. Swain (Springer, Singapore, 2021), pp. 285-305

29. T.Q. Bui, S.N.-C. Ton, A.T. Duong, H.T. Tran, Journal of Science: Advanced Materials and Devices 3, 107 (2018)

30. A. Radoń, A. Drygała, Ł Hawełek, D. Łukowiec, Mater. Charact. 131, 148 (2017)

31. M. Anbarasu, M. Anandan, E. Chinnasamy, V. Gopinath, K. Balamurugan, Spectrochim. Acta Part A Mol. Biomol. Spectrosc. 135, 536 (2015)

32. S. Tong, C.A. Quinto, L. Zhang, P. Mohindra, G. Bao, ACS Nano 11, 6808 (2017)

33. L. Chaabane, H. Chahdoura, R. Mehdaoui, M. Snoussi, E. Beyou, M. Lahcini, M.H.V. Baouab, Carbohyd. Polym. 247, 116707 (2020) 34. E.D. Smolensky, M.C. Neary, Y. Zhou, T.S. Berquo, V.C. Pierre, Chem. Commun. 47, 2149 (2011)

35. M. Seifan, A.K. Sarmah, A.K. Samani, A. Ebrahiminezhad, Y. Ghasemi, A. Berenjian, Appl Microbiol Biotechnol 102, 4489 (2018)

36. M. Namdeo, S. Saxena, R. Tankhiwale, M. Bajpai, Y.M. Mohan, S.K. Bajpai, J. Nanosci. Nanotechnol. 8, 3247 (2008)

37. F. Assa, H. Jafarizadeh-Malmiri, H. Ajamein, H. Vaghari, N. Anarjan, O. Ahmadi, A. Berenjian, Crit. Rev. Biotechnol. 37, 492 (2017)

38. G.M. Ziarani, M. Malmir, N. Lashgari, A. Badiei, RSC Advances 9, 25094 (2019)

39. Y.T. Prabhu, K.V. Rao, B.S. Kumari, V.S.S. Kumar, T. Pavani, Int Nano Lett 5, 85 (2015)

40. H. Zhang, G. Zhu, Appl. Surf. Sci. 258, 4952 (2012)

41. S. Ahmadian-Fard-Fini, M. Salavati-Niasari, D. Ghanbari, Spectrochim. Acta Part A Mol. Biomol. Spectrosc. 203, 481 (2018)

42. S. Arjo, M.N. Hidayat, N. Suminten, B. Nurjanati, S. Husain, J. Phys.: Conf. Ser. 1796, 012026 (2021)

43. O.M. Lemine, K. Omri, B. Zhang, L. El Mir, M. Sajieddine, A. Alyamani, M. Bououdina, Superlattices Microstruct. 52, 793 (2012)

44. Z. Takai, M. Mustafa, S. Asman, K. Sekak, International Journal of Nanoelectronics and Materials 12, 37 (2019)

45. I.S. Smolkova, N.E. Kazantseva, H. Parmar, V. Babayan, P. Smolka, P. Saha, Mater. Chem. Phys. 155, 178 (2015)

46. R. Mehdaoui, L. Chaabane, E. Beyou, M.H.V. Baouab, J IRAN CHEM SOC 16, 645 (2019)

47. R. Mehdaoui, S. Agren, A. Dhahri, J. Bennagi, E. Beyou, M. Lahcini, M. Baouab, Applied Organometallic Chemistry 35, (2021)

48. A.D. Becke, J. Chem. Phys. 98, 5648 (1993)

49. S. Grimme, J. Antony, S. Ehrlich, H. Krieg, J. Chem. Phys. 132, 154104 (2010)

50. (n.d.)

51. S. Raoudha, M. Chaabene, M. Jabli, T. Saleh, R. Chaabane, E. Saint-Aman, F. Loiseau, C. Philouze, A.-R. Allouche, H. Nasri, The Chemical Engineering Journal 375, (2019)

52. L. Mohamed, M. Chaabene, K. Mourad Shady, R. Chaabane, B. Jamoussi, and gallot-lavallée olivier. Physica B Condensed Matter 565, 48 (2019)

53. S. Tomić, B. Montanari, N.M. Harrison, Physica E: Low-Dimensional Systems and Nanostructures 40, 2125 (2008)

54. K. Wolinski, J.F. Hinton, P. Pulay, J. Am. Chem. Soc. 112, 8251 (1990)

55. S. Raoudha, M. Chaabene, M. Jabli, Y. Rousselin, J. Solid State Chem. 295, 121920 (2021)

56. R. Johnson, (2002)

57. M. Chaabene, S. Agren, J. Bennagi, A.-R. Allouche, L. Mohamed, R. Chaabane, M. Baouab, Journal of Molecular Structure 130962 (2021)

58. M. Chaabene, B. Gassoumi, P. Mignon, R. Ben, Chaâbane, A.-R. Allouche, J. Mol. Graph. Model. 88, 174 (2019)

59. M. Chaabene, B. Gassoumi, R. Soury, H. Ghalla, M. Jabli, R. Ben, Chaâbane, A.-R. Allouche, Chem. Phys. 547, 111198 (2021)

Page 15/23 
60. J.-L. Calais, Int. J. Quantum Chem. 47, 101 (1993)

61. E. Eren, B. Afsin, J. Hazard. Mater. 151, 682 (2008)

62. M.A. Neelakantan, S.S. Marriappan, J. Dharmaraja, T. Jeyakumar, K. Muthukumaran, Spectrochim. Acta Part A Mol. Biomol. Spectrosc. 71, 628 (2008)

63. Z.I. Taka, M.K. Mustafa, S. Asman, K.A. Sekak, J. Muhammada, International Journal of Engineering \& Technology 7, 185 (2018)

64. R. Mehdaoui, A. EL, W. GHALI, E. Cheikhrouhou, Beyou, M. Baouab, Iranian Polymer Journal 26, (2017)

65. R. Pervin, K.A. Khan, N.I. Khan, A.K.M. Atique Ullah, and S. M. Zian Reza, in Advances in Medical Physics and Healthcare Engineering, edited by M. Mukherjee, J. K. Mandal, S. Bhattacharyya, C. Huck, and S. Biswas (Springer, Singapore, 2021), pp. 81-91

66. A. Gandon, C.C. Nguyen, S. Kaliaguine, T.O. Do, The Canadian Journal of Chemical Engineering 99, 479 (2021)

67. O.A. El-Gammal, A.F. Al-Hossainy, S.A. El-Brashy, J. Mol. Struct. 1165, 177 (2018)

68. D.F. Marsh, R.E. Falvo, L.M. Mink, J. Chem. Educ. 76, 237 (1999)

69. N. Raman, C. Thangaraja, Transition Met. Chem. 3, 317 (2005)

70. C. Chachaty, P. Rigny, J. Chim. Phys. 79, 203 (1982)

71. M.K. Subramanian, P.M. Anbarasan, V. Ilangovan, N. Sundaraganesan, Mol. Simul. 34, 277 (2008)

72. C.R. Jacob, M. Reiher, J. Chem. Phys. 130, 084106 (2009)

73. X. Cheng, J.J. Talbot, R.P. Steele, J. Chem. Phys. 145, 124112 (2016)

74. J. Manonmani, R. Thirumuruhan, M. Kandaswamy, V. Narayanan, S. Shanmuga Sundara, M.N. Raj, G. Ponnuswamy, Shanmugam, H.K. Fun, Polyhedron 20, 3039 (2001)

75. S. Ilhan, H. Temel, I. Yilmaz, M. Sekerci, J. Organomet. Chem. 18, 3855 (2007)

76. K. Kumara, A. Dileep Kumar, S. Naveen, K. Ajay Kumar, N.K. Lokanath, J. Mol. Struct. 1161, 285 (2018)

77. K. Kumara, A.D. Kumar, K.A. Kumar, N.K. Lokanath, Chemical Data Collections 13-14, 40 (2018)

78. M. Chaabene, S. Agren, A.-R. Allouche, M. Lahcinie, R.B. Chaâbane, M.H.V. Baouab, Appl. Organomet. Chem. 33 , e5218 (2019)

79. S. Agren, M. Chaabene, A. Allouche, R. Ben Chaâbane, M. Lahcinie, M.H.V. Baouab, Appl Organomet Chem (2020)

80. W. Wu, Q. He, C. Jiang, Nanoscale Res Lett 3, 397 (2008)

81. V.A.J. Silva, P.L. Andrade, M.P.C. Silva, A. Bustamante, D., L. De Los Santos Valladares, and J. Albino Aguiar. J. Magn. Magn. Mater. 343, 138 (2013)

82. A. Bezaatpour, F. Payami, H. Eskandari, C. R. Chim. 20, 910 (2017)

83. B. Khan, M. Nawaz, G.J. Price, R. Hussain, A. Baig, S. Haq, W. Rehman, M. Waseem, Chem. Pap. 75, 5339 (2021)

84. K. Kydralieva, L. Bondarenko, V. Terekhova, N. Chistyakova, S. Patsaeva, L. Rabinskiy, G. Dzhardimalieva, Materials Today: Proceedings 34, 317 (2021)

85. R.G.D. Andrade, S.R.S. Veloso, E.M.S. Castanheira, Int. J. Mol. Sci. 21, 2455 (2020)

86. M. Soleymani, S. Khalighfard, S. Khodayari, H. Khodayari, M.R. Kalhori, M.R. Hadjighassem, Z. Shaterabadi, A.M. Alizadeh, Sci Rep 10, 1695 (2020)

87. P. Hariani, M. Faizal, R. Syarofi, M. Marsi, D. Setiabudidaya, Int. J. Environ. Sci. Dev. 4, 336 (2013)

88. S. Koesnarpadi, W. Astuti, I.Y. Lianasari, AIP Conference Proceedings 2237, 020022 (2020)

89. M. Kooti, S. Gharineh, M. Mehrkhah, A. Shaker, H. Motamedi, Chem. Eng. J. 259, 34 (2015)

90. M. Maccarini, A. Atrei, C. Innocenti, R. Barbucci, Colloids Surf., A 462, 107 (2014)

\section{Figures}



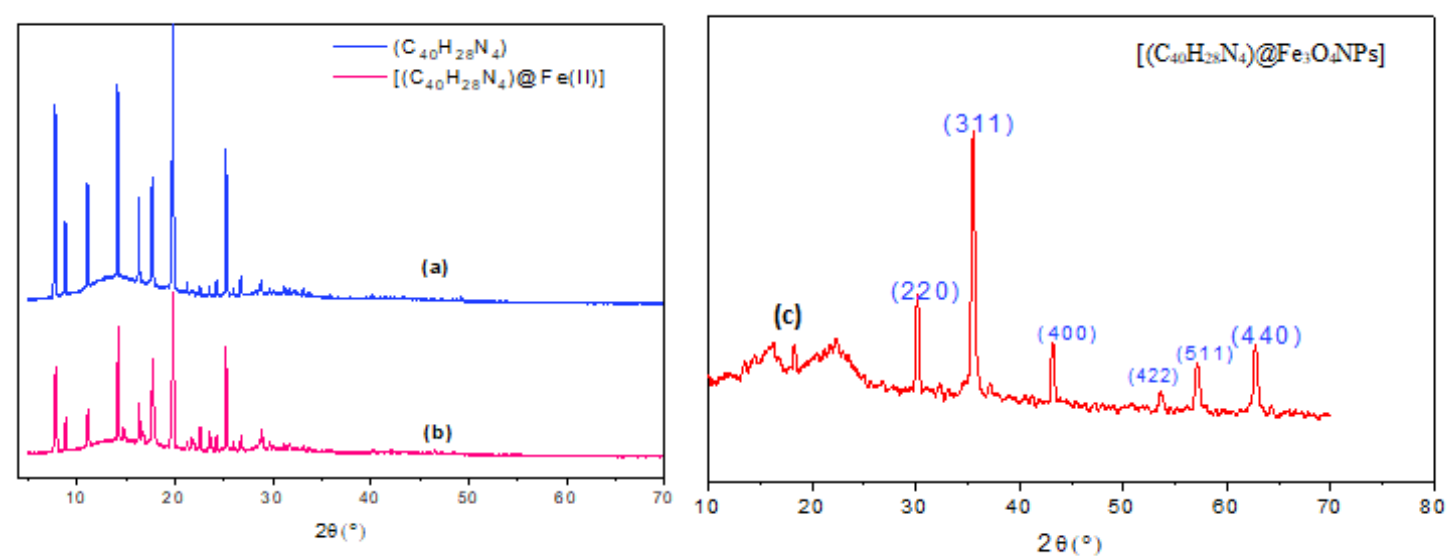

Figure 1

The X-ray diffraction patterns of (a) ligand $\left(\mathrm{C}_{40} \mathrm{H}_{28} \mathrm{~N}_{4}\right)$, (b) $\left[\left(\mathrm{C}_{40} \mathrm{H}_{28} \mathrm{~N}_{4}\right) @ \mathrm{Fe}(\mathrm{II})\right]$ and (c) $\left[\left(\mathrm{C}_{40} \mathrm{H}_{28} \mathrm{~N}_{4}\right) @ \mathrm{Fe}_{3} \mathrm{O}_{4} \mathrm{NPs}\right]$.

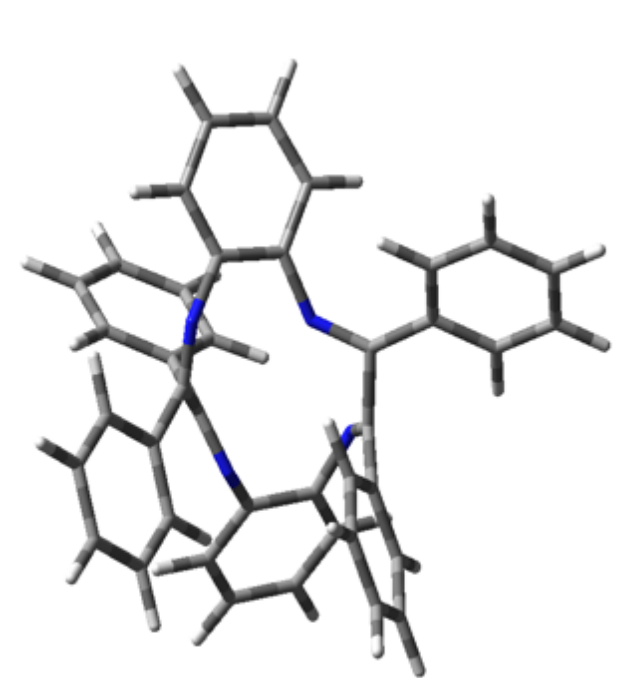

(a)

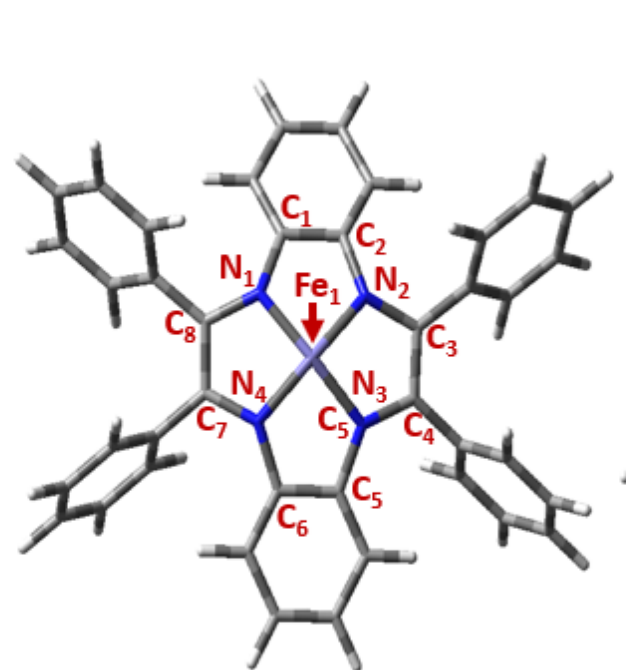

(b)

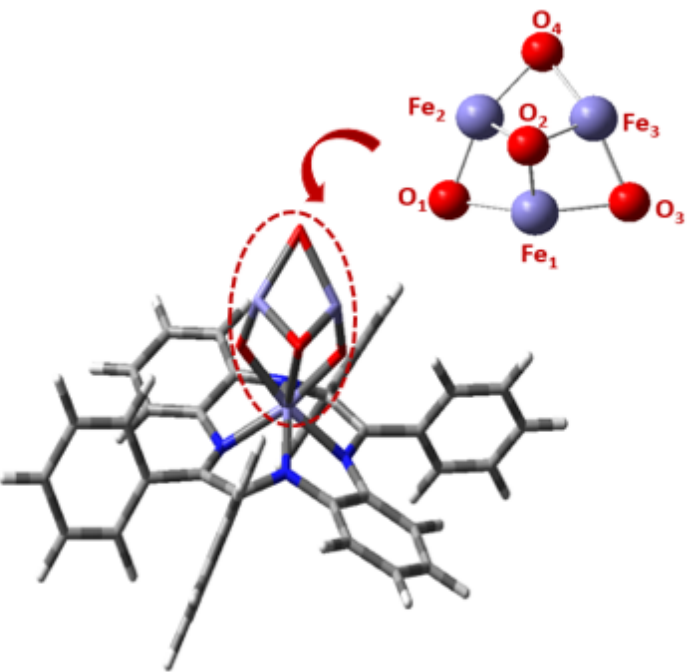

(c)

Figure 2

The optimized structures of (a) the ligand $\left(\mathrm{C}_{40} \mathrm{H}_{28} \mathrm{~N}_{4}\right)$, (b) $\left[\mathrm{Fe}\left(\mathrm{C}_{40} \mathrm{H}_{28} \mathrm{~N}_{4}\right)\right]$ and (c) $\left[\left(\mathrm{C}_{40} \mathrm{H}_{28} \mathrm{~N}_{4}\right) @ \mathrm{Fe}_{3} \mathrm{O}_{4} \mathrm{NPs}\right]$ using B3LYP-D3/6-311 G (d, p) level of theory. 

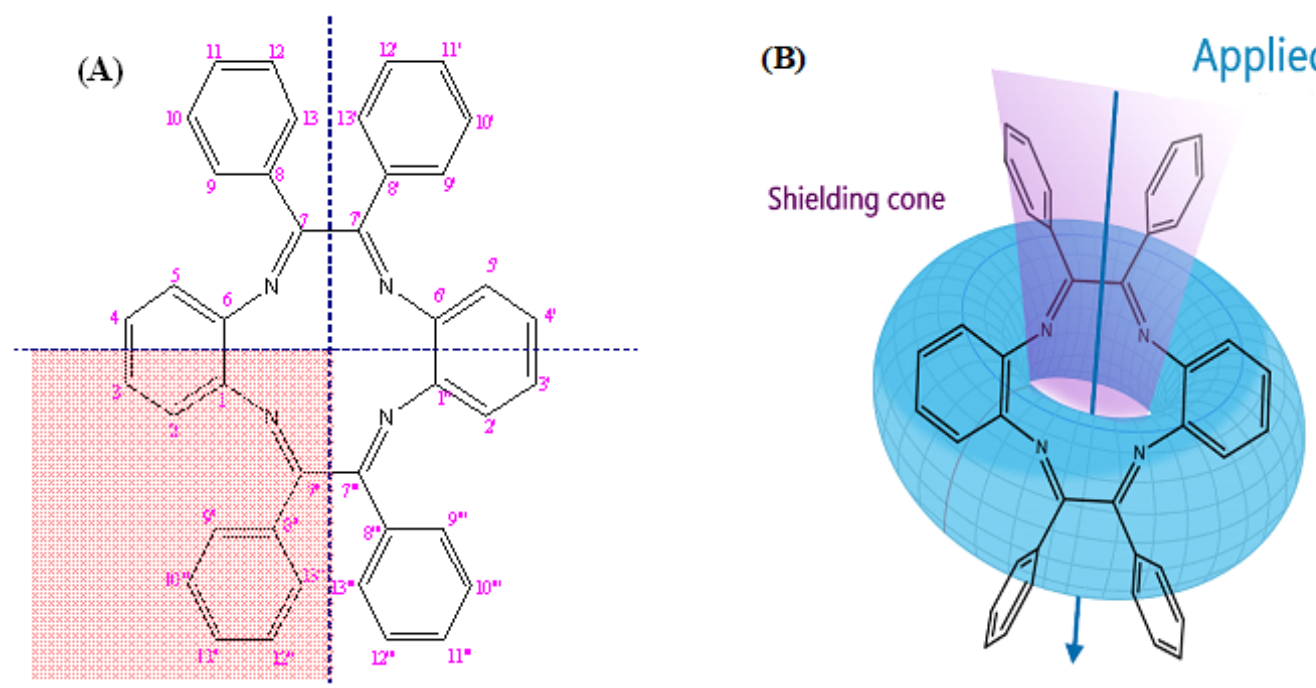

\section{Figure 3}

(A) The double symmetry of the macrocyclic ligand $\left(\mathrm{C}_{40} \mathrm{H}_{28} \mathrm{~N}_{4}\right)$; Magnetic anisotropy of the ligand $\left(\mathrm{C}_{40} \mathrm{H}_{28} \mathrm{~N}_{4}\right)$.
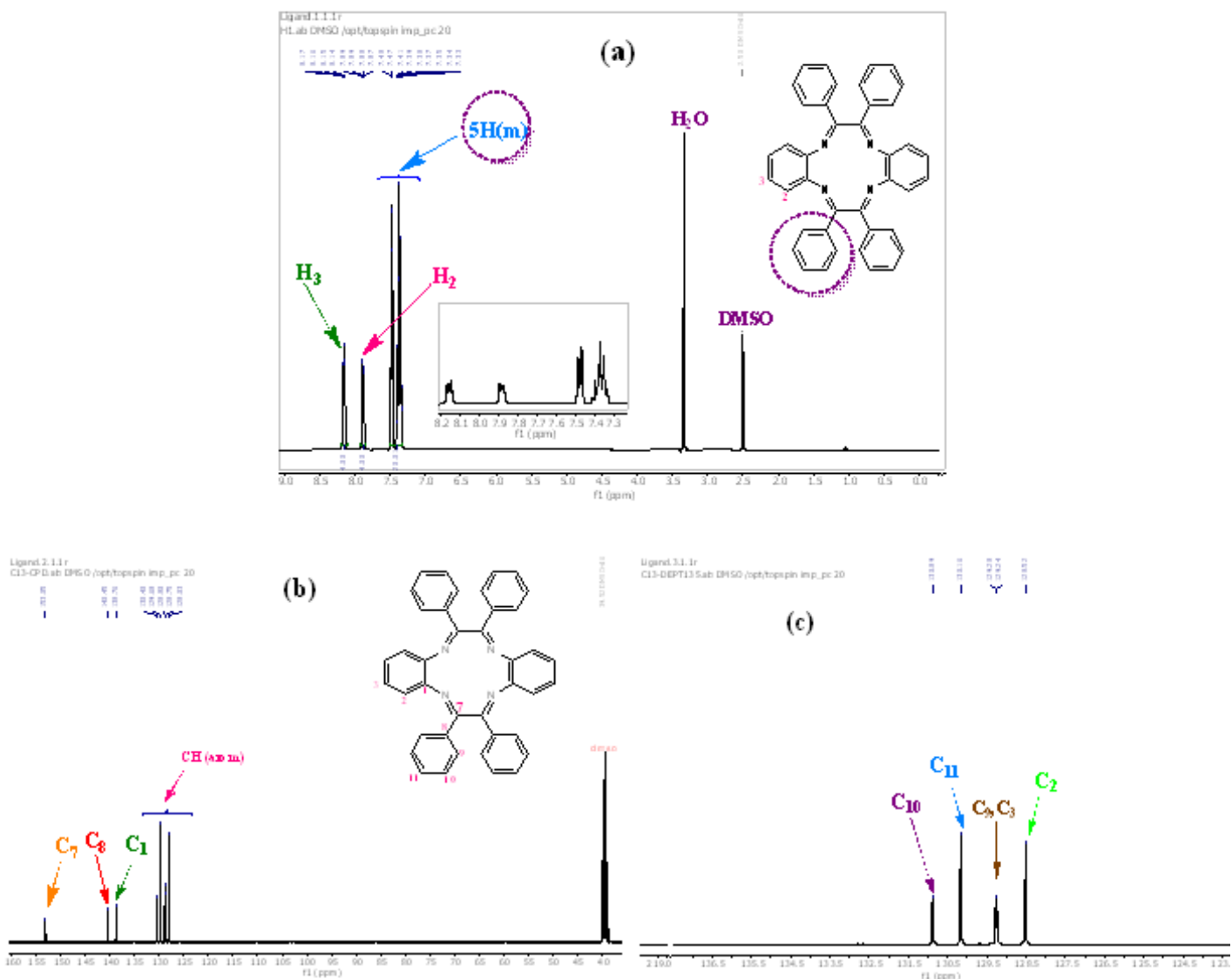

Figure 4 
(a) ${ }^{1} \mathrm{H}$ NMR, (b) ${ }^{13} \mathrm{C}$ NMR and (c) (DEPT135) spectra of the macrocyclic ligand $\left(\mathrm{C}_{40} \mathrm{H}_{28} \mathrm{~N}_{4}\right)$.
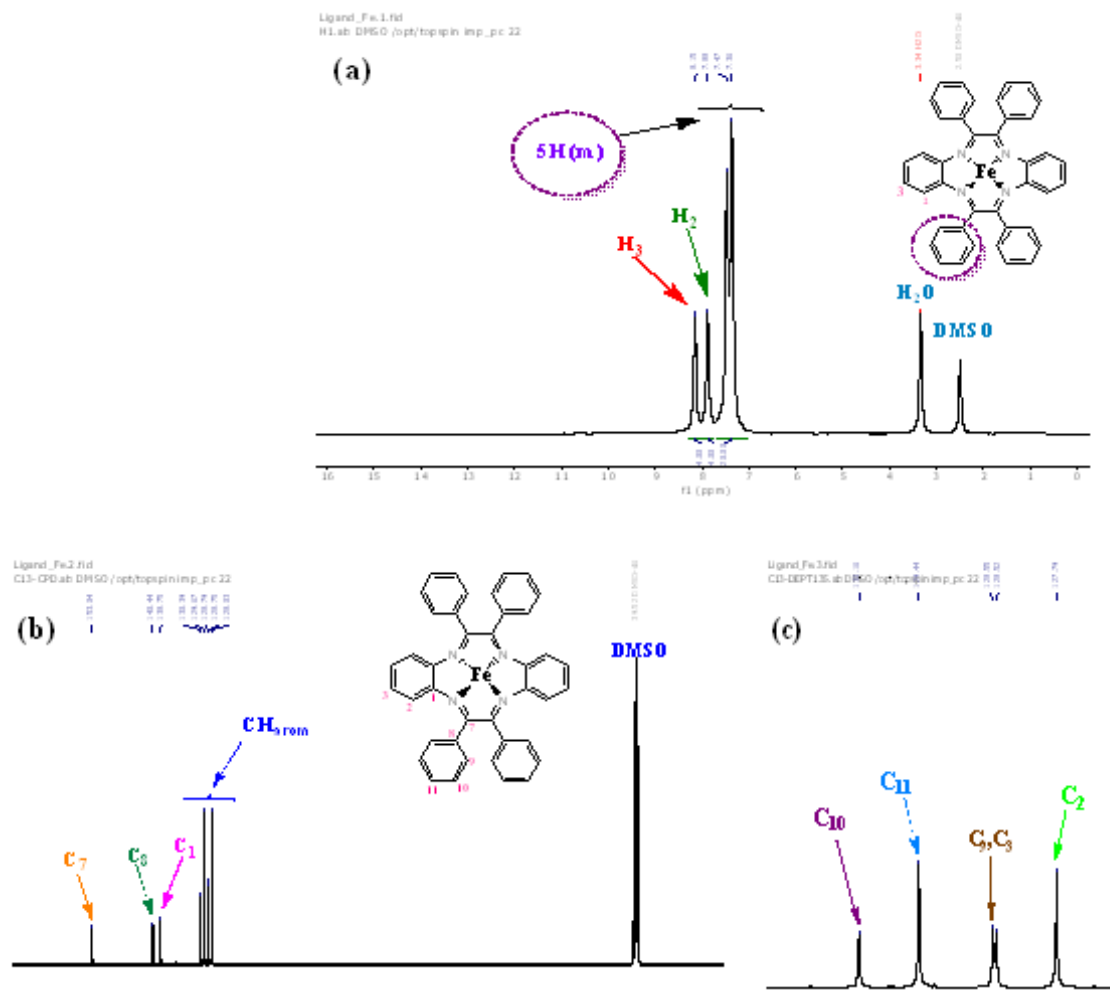

(c)

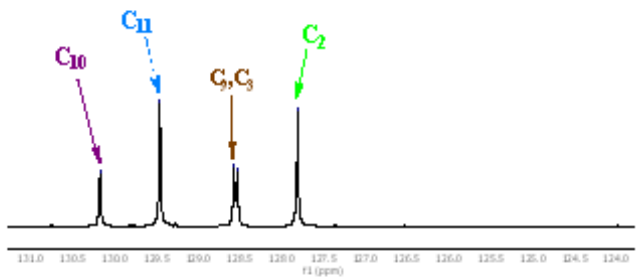

\section{Figure 5}

(a) ${ }^{1} \mathrm{H}$ NMR, (b) ${ }^{13} \mathrm{C}$ NMR, and (c) (DEPT135) spectra of the $\left[\left(\mathrm{C}_{40} \mathrm{H}_{28} \mathrm{~N}_{4}\right) @ \mathrm{Fe}(\mathrm{II})\right]$ complex.

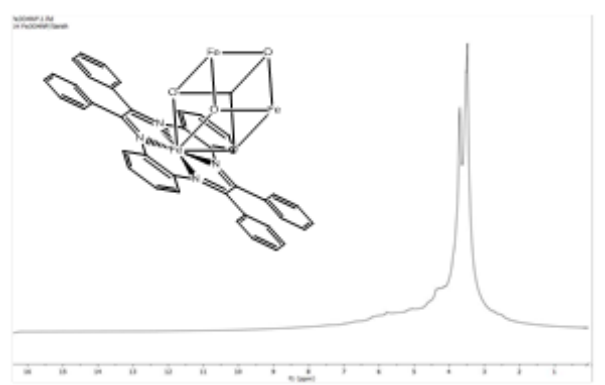

\section{Figure 6}

${ }^{1} \mathrm{H}$ NMR spectra of the $\left[\left(\mathrm{C}_{40} \mathrm{H}_{28} \mathrm{~N}_{4}\right) @ \mathrm{Fe}_{3} \mathrm{O}_{4} \mathrm{NPs}\right]$ complex. 

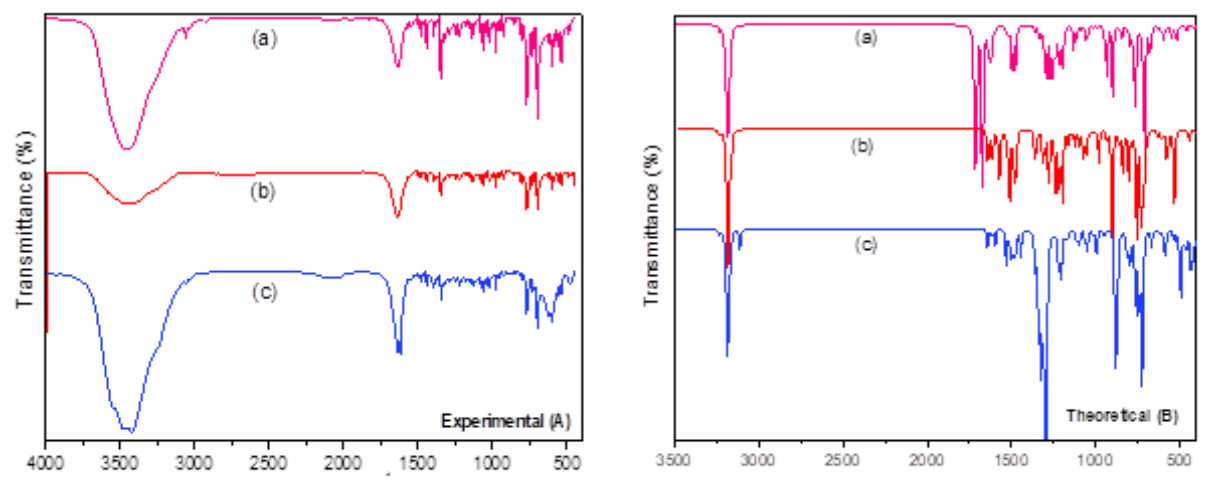

Figure 7

Comparison of experimental and theoretical FT-IR of (a) ligand $\left(\mathrm{C}_{40} \mathrm{H}_{28} \mathrm{~N}_{4}\right),\left(\right.$ b) $\left[\left(\mathrm{C}_{40} \mathrm{H}_{28} \mathrm{~N}_{4}\right) @ \mathrm{Fe}(\mathrm{II})\right]$ and (c) $\left[\left(\mathrm{C}_{40} \mathrm{H}_{28} \mathrm{~N}_{4}\right) @ \mathrm{Fe} \mathrm{O}_{3} \mathrm{O}_{4} \mathrm{NPs}\right]$.
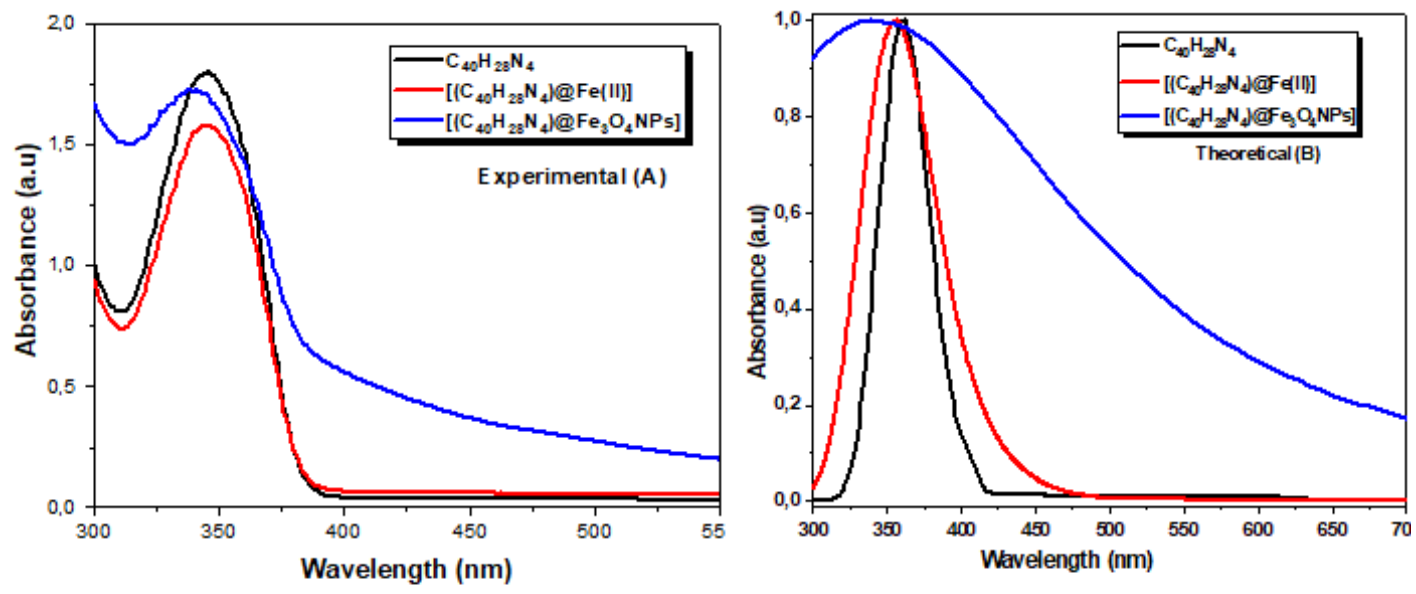

\section{Figure 8}

Comparison of experimental and theoretical UV-Visible of (a) ligand $\left(\mathrm{C}_{40} \mathrm{H}_{28} \mathrm{~N}_{4}\right)$, (b) $\left[\left(\mathrm{C}_{40} \mathrm{H}_{28} \mathrm{~N}_{4}\right) @ \mathrm{Fe}(\mathrm{II})\right]$, and (c) $\left[\left(\mathrm{C}_{40} \mathrm{H}_{28} \mathrm{~N}_{4}\right) @ \mathrm{Fe} \mathrm{O}_{3} \mathrm{O}_{4} \mathrm{NPs}\right]$. 

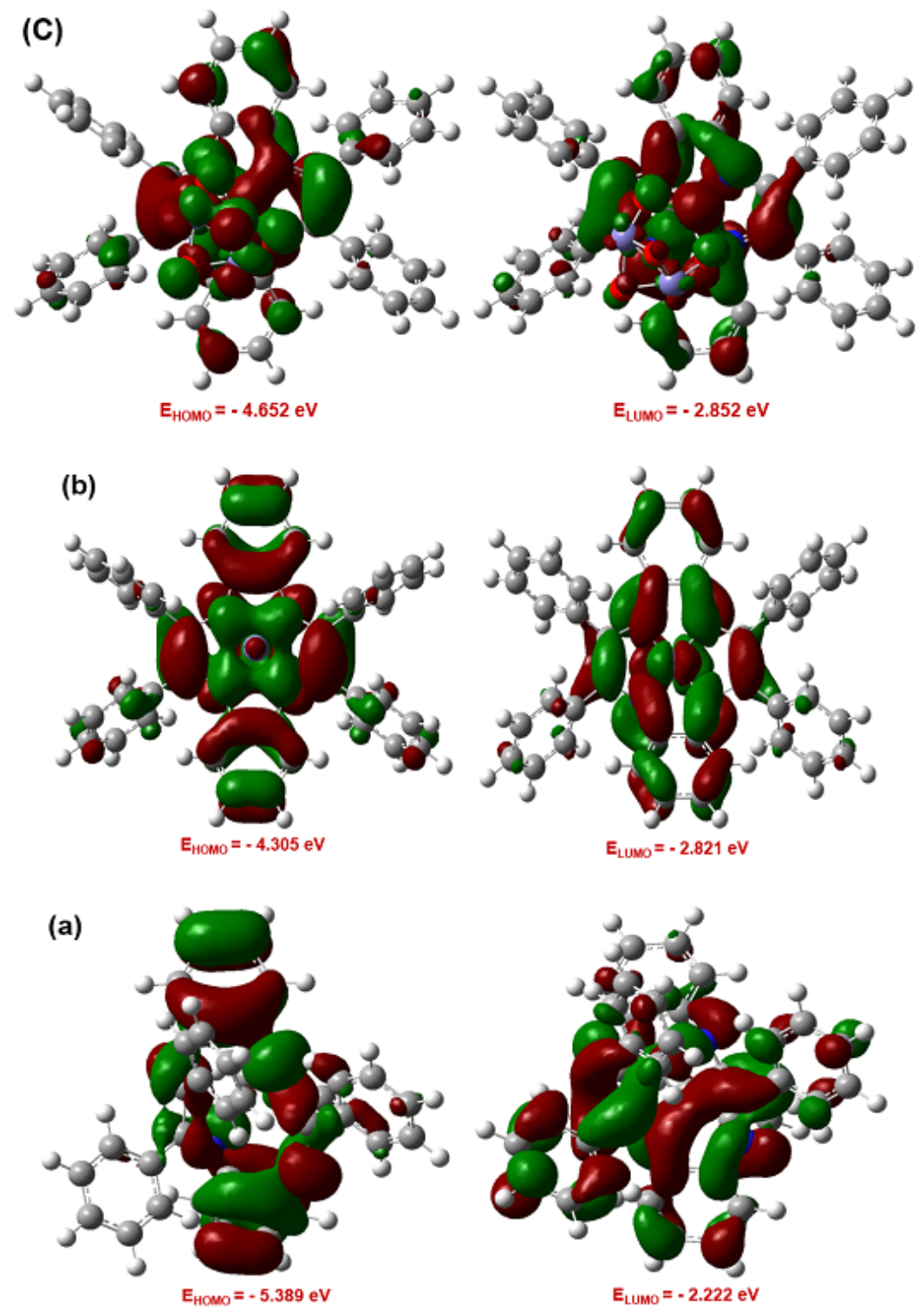

Figure 9

Calculated frontier molecular orbitals of (a), (b) and (c) in DMSO solvent with CAM-B3LYP-D3 method. 

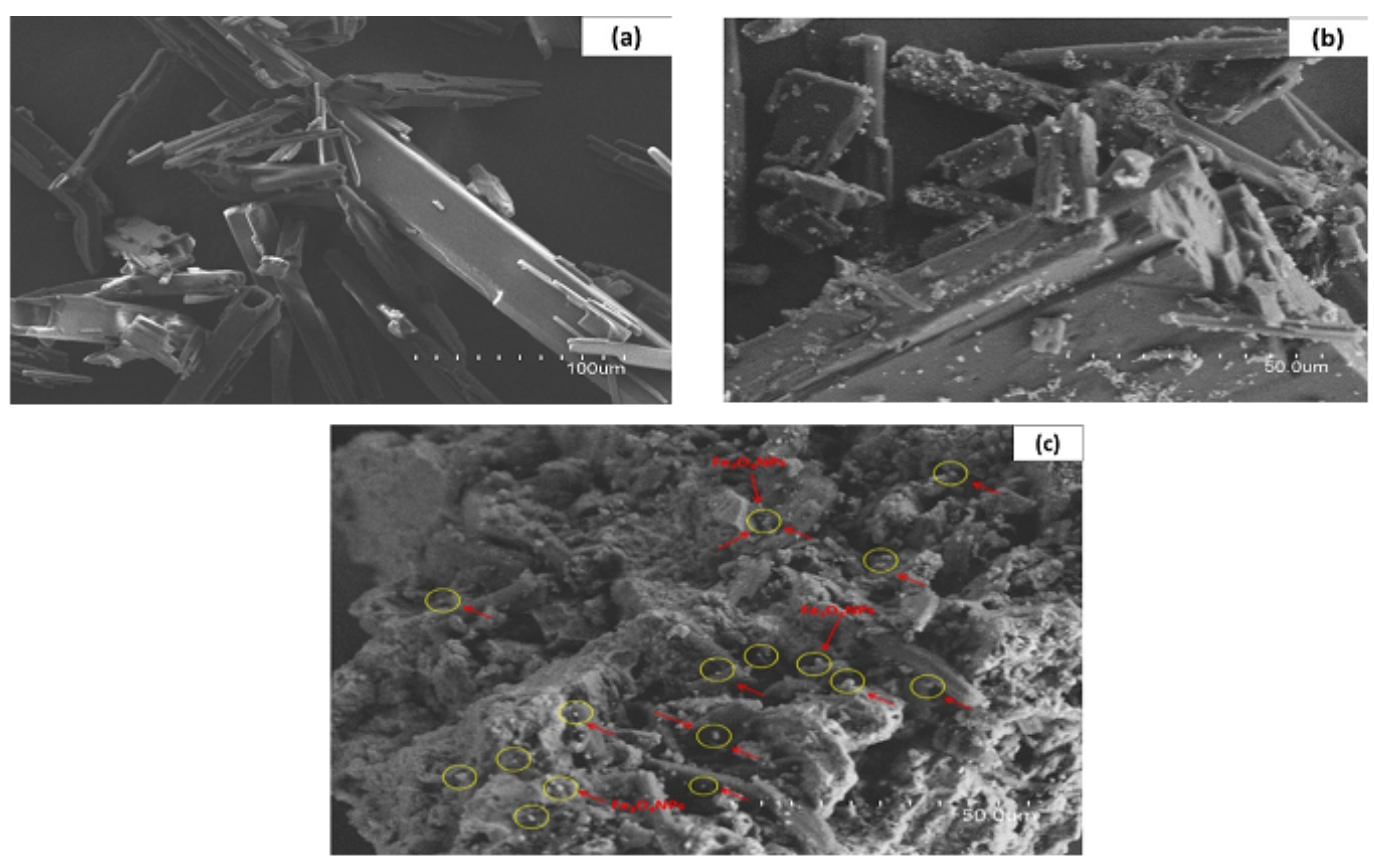

Figure 10

SEM micrographs of (a) ligand $\left(\mathrm{C}_{40} \mathrm{H}_{28} \mathrm{~N}_{4}\right)$, (b) $\left[\left(\mathrm{C}_{40} \mathrm{H}_{28} \mathrm{~N}_{4}\right) @ \mathrm{Fe}(\mathrm{II})\right]$ and (c) $\left[\left(\mathrm{C}_{40} \mathrm{H}_{28} \mathrm{~N}_{4}\right) @ \mathrm{Fe} \mathrm{O}_{3} \mathrm{NPs}\right]$ samples.
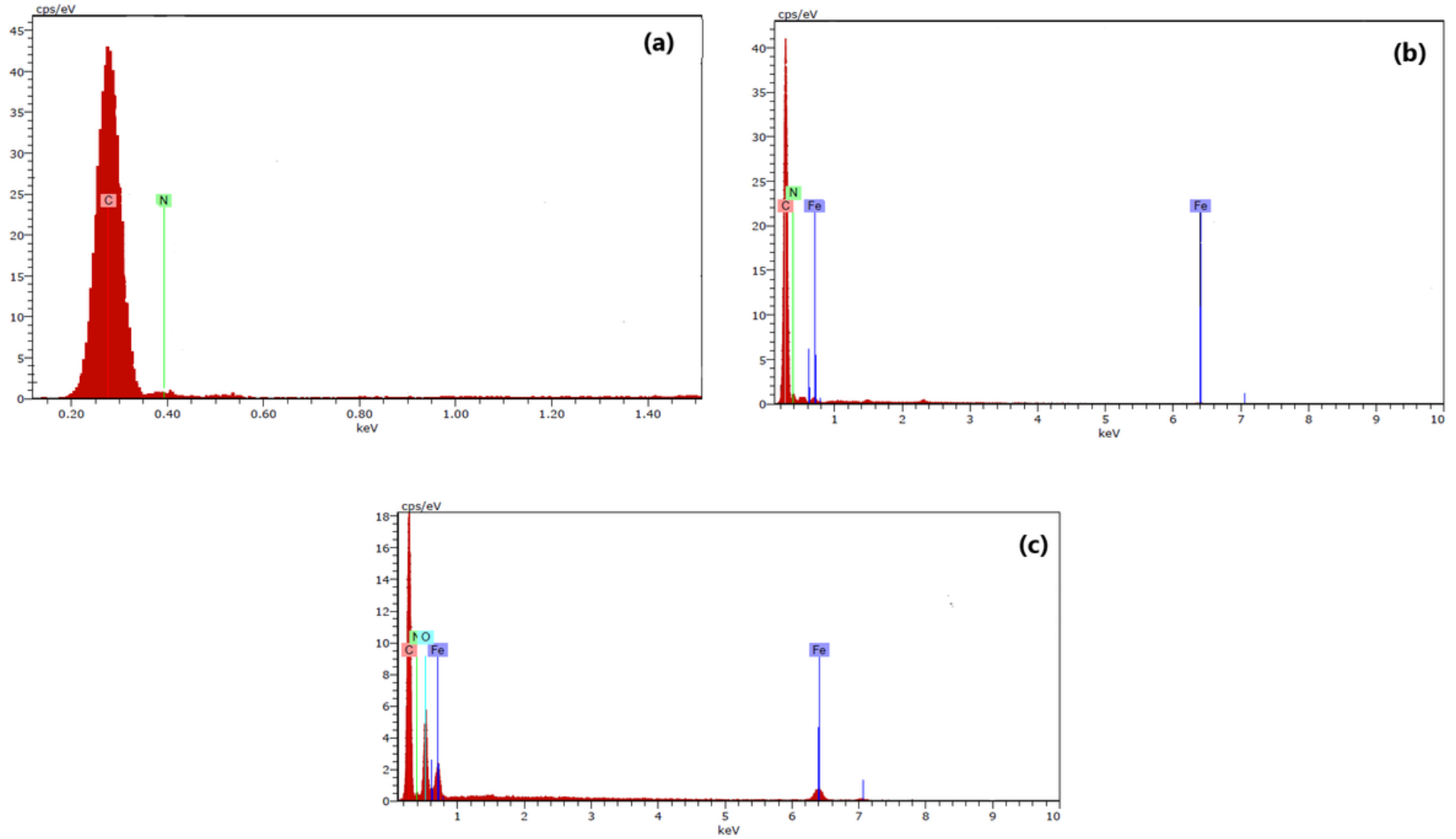

Figure 11 
EDX spectra of (a) ligand $\left(\mathrm{C}_{40} \mathrm{H}_{28} \mathrm{~N}_{4}\right),\left(\right.$ b) $\left[\left(\mathrm{C}_{40} \mathrm{H}_{28} \mathrm{~N}_{4}\right) @ \mathrm{Fe}(\mathrm{II})\right]$ and $(\mathbf{c})\left[\left(\mathrm{C}_{40} \mathrm{H}_{28} \mathrm{~N}_{4}\right) @ \mathrm{Fe}_{3} \mathrm{O}_{4} \mathrm{NPs}\right]$ samples.

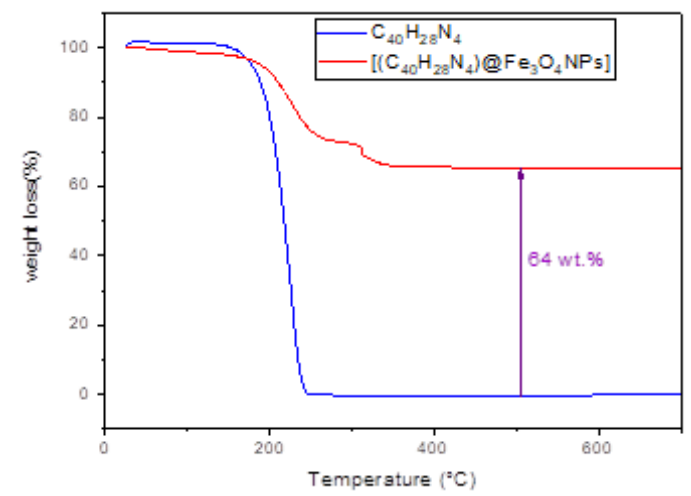

Figure 12

TGA curves of $\mathrm{C}_{40} \mathrm{H}_{28} \mathrm{~N}_{4}$ ligand, and $\left[\left(\mathrm{C}_{40} \mathrm{H}_{28} \mathrm{~N}_{4}\right) @ \mathrm{Fe}_{3} \mathrm{O}_{4} \mathrm{NPs}\right]$ complex.

(a)

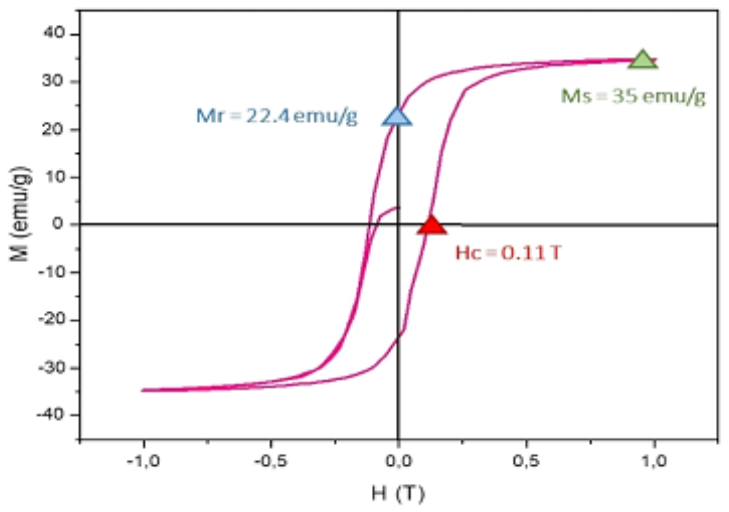

(b)

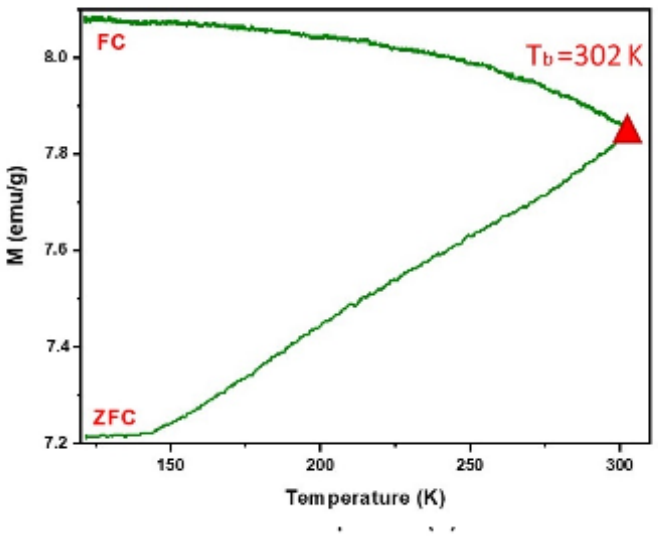

Figure 13

(a) Magnetization curves measured at $300 \mathrm{~K}$ for the $\left[\left(\mathrm{C}_{40} \mathrm{H}_{28} \mathrm{~N}_{4}\right) @ \mathrm{Fe}_{3} \mathrm{O}_{4} \mathrm{NPs}\right]$; (b) zero-field-cooled (ZFC) and field-cooled (FC) magnetization curves for $\left[\left(\mathrm{C}_{40} \mathrm{H}_{28} \mathrm{~N}_{4}\right) @ \mathrm{Fe}_{3} \mathrm{O}_{4} \mathrm{NPs}\right]$ (applied field $=9 \times 10^{-3} \mathrm{~T}$ and temperature range $=100-300 \mathrm{~K}$. 